\title{
NEW RADIOCARBON DATES AND A REVIEW OF THE CHRONOLOGY OF PREHISTORIC POPULATIONS FROM THE MINUSINSK BASIN, SOUTHERN SIBERIA, RUSSIA
}

\author{
Svetlana V Svyatko ${ }^{1,2} \bullet$ James P Mallory $^{1} \bullet$ Eileen M Murphy $^{1} \bullet$ Andrey V Polyakov $^{3} \bullet$ \\ Paula J Reimer ${ }^{1} \cdot$ Rick J Schulting $^{4}$
}

\begin{abstract}
The results are presented of a new program of radiocarbon dating undertaken on 88 human skeletons. The individuals derived from Eneolithic to Early Iron Age sites-Afanasievo, Okunevo, Andronovo (Fedorovo), Karasuk, and Tagar cultures-in the Minusinsk Basin of Southern Siberia. All the new dates have been acquired from human bone, which is in contrast to some of the previous dates for this region obtained from wood and thus possibly unreliable due to old-wood effects or re-use of the timber. The new data are compared with the existing ${ }^{14} \mathrm{C}$ chronology for the region, thereby enabling a clearer understanding to be gained concerning the chronology of these cultures and their place within the prehistory of the Eurasian steppes.
\end{abstract}

\section{INTRODUCTION}

The results of radiocarbon dating are of particular importance for the establishment of the chronology of cultures not recorded in written sources, as is the case for most of the cultures of prehistoric Southern Siberia. Some of the first ${ }^{14} \mathrm{C}$ dates obtained for the prehistoric complexes of Southern Siberia (Scythian monuments of the Altai Mountain region) were published in Radiocarbon in 1965 (Butomo 1965), and since then the various aspects of the area's ${ }^{14} \mathrm{C}$ chronology have been presented and discussed in its pages (e.g. Sementsov et al. 1969, 1998; Semyontsov et al. 1972; Görsdorf et al. 1998b, 2001; Alekseev et al. 2001; Zaitseva et al. 2004). The following paper focuses on the chronology of the prehistoric populations of the Minusinsk Basin, Southern Siberia, and presents new ${ }^{14} \mathrm{C}$ dates and a review of the previous understanding of the region's chronology.

The Minusinsk Basin is a region of Southern Siberia and is located in the territory of the modern Republic of Khakasia and the Krasnoyarsk Province in the middle valley of the river Yenisey and upper valley of the river Chulym. It comprises 4 smaller basins-the Nazarovo, Chulym-Yenisey, Syda-Erba, and Minusinsk basins (henceforth the term "minor Minusinsk Basin" will be used throughout the text to avoid confusion; see Figure 1). The first division of the prehistoric cultures of the area into periods was devised during the 1920s by S A Teploukhov (1929) and the situation did not change until the 1960s, when the Okunevo culture of the Early Bronze Age was identified (Maksimenkov 1965, 1968a,b, 1975a,b). Archaeologists currently believe that archaeological cultures, ranging in date from the Eneolithic through to the Iron Age, successively lived in the region from the 25 th century BC to the 1 st century AD (Table 1).

The traditional chronology of the steppe cultures was originally established on the basis of crosscultural synchronization with Chinese bronzes, with European sites, and on 1 occasion with "Mycenaean" ornaments (Kuzmina 2007:459-466). The traditional chronology, however, has appeared to be in conflict with the dating sequence derived on the basis of ${ }^{14} \mathrm{C}$ dates, particularly for the cultures

\footnotetext{
${ }^{1}$ School of Geography, Archaeology \& Palaeoecology, Queen's University Belfast, Belfast BT7 1NN, Northern Ireland, United Kingdom.

${ }^{2}$ Corresponding author. Email: ssvyatko01@qub.ac.uk.

${ }^{3}$ Institute for the History of Material Culture, Russian Academy of Sciences, 18 Dvortsovaya Embankment, St Petersburg 191186, Russia.

${ }^{4}$ School of Archaeology, University of Oxford, 36 Beaumont Street, Oxford OX1 2PG, England, United Kingdom.
}

(C) 2009 by the Arizona Board of Regents on behalf of the University of Arizona Celebrating 50 Years of Radiocarbon

RADIOCARBON, Vol 51, Nr 1, 2009, p 243-273 


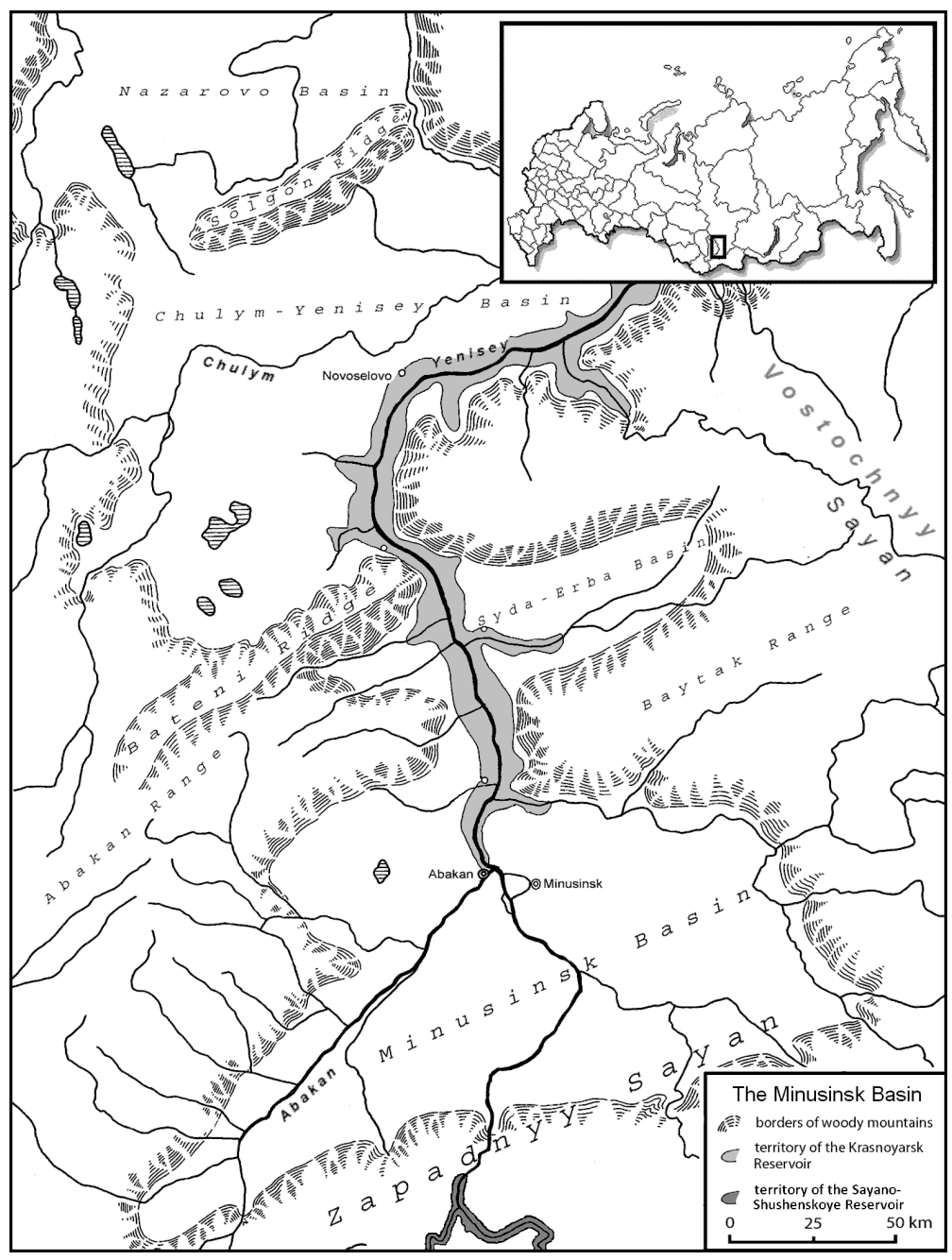

Figure 1 Location of the Minusinsk Basin (modified after Vadetskaya 1986)

Table 1 Eneolithic to Early Iron Age cultures of the Minusinsk Basin and their periodization.

\begin{tabular}{llll}
\hline Culture & Period & Traditional dating & ${ }^{14} \mathrm{C}$ dating \\
\hline Afanasievo $^{\mathrm{a}}$ & Eneolithic & 25th-20th centuries BC & 37th-25th centuries BC \\
Okunevo $^{\text {Andronovo }}{ }^{\text {a }}$ & Bronze Age & 19th-17th/16th centuries BC & 25th-19th centuries BC \\
Karasuk & & 17th/16th-13th centuries BC & 19th-15th centuries BC \\
Tagar & Early Iron Age & 13th-8th centuries BC & 14th-10th centuries BC \\
a The dates are presented only for Minusinsk Basin sites. &
\end{tabular}

of the Middle Yenisey area. Since the 1960s, more than $270{ }^{14} \mathrm{C}$ dates have been obtained for the 5 prehistoric cultures of the Minusinsk Basin (Appendices 1-5). The results have tended to suggest that the cultures are older, and in some cases considerably older, than traditional archaeological dates, based on cross-correlation of material culture (e.g. Görsdorf et al. 2001:1117; Alekseev et al. 2005:223; Table 1). The discussion over the discrepancy between the archaeological and ${ }^{14} \mathrm{C}$ dating of the populations is still ongoing. 
Only a few attempts have been made to summarize the ${ }^{14} \mathrm{C}$ data obtained for the area's prehistoric populations (e.g. Scott et al. 2004; Alekseev et al. 2005; Kuzmin 2008). The current paper will not only attempt to synthesize the results of all prior ${ }^{14} \mathrm{C}$ studies for the region, but will also greatly augment this corpus of information with the addition of 88 new ${ }^{14} \mathrm{C}$ dates. This dating program is part of an ongoing research project that aims to explore the complex interrelationships between the environment, lifestyle, and diet of the prehistoric populations of the Minusinsk Basin. The new dates have been obtained from adult human skeletons derived from various cemeteries of the Afanasievo, Okunevo, Andronovo, Karasuk, and Tagar cultures (see Tables 3, 5, 8, 10, and 13). The paper will discuss how the new series of ${ }^{14} \mathrm{C}$ dates compare to the current archaeological and ${ }^{14} \mathrm{C}$ models for the emergence and development of the different prehistoric cultures of the Minusinsk Basin.

\section{MATERIALS AND METHODS}

A total of 88 adult human bone samples were taken for accelerator mass spectrometer (AMS) ${ }^{14} \mathrm{C}$ dating. Adult individuals of both sexes and different age categories were sampled. Samples of $2 \mathrm{~g}$ of cortical bone were taken from different parts of the skeleton, with the objective of retrieving a suitable sample of bone while causing minimal damage to the skeleton. All samples were prepared at the ${ }^{14} \mathrm{CHRONO}$ Centre for Climate, the Environment, and Chronology, Queen's University Belfast. The bone collagen was extracted following the ultrafiltration method described in Brown et al. (1988), using Vivaspin ${ }^{\mathrm{TM}}$ filters cleaned to remove glycerin used to preserve the filter membrane, 2 centrifugations with ultrapure water (MilliQ ${ }^{\mathrm{TM}}$ ), ultrasonication in MilliQ water, and 3 more centrifugations with MilliQ following the method of Bronk Ramsey et al. (2004). In summary, the bone was decalcified in $2 \%$ hydrochloric acid $(\mathrm{HCl})$, followed by protein lysing in $\mathrm{HCl}(\mathrm{pH} 2)$ in a culture tube that was placed on a heating block at a temperature of $58{ }^{\circ} \mathrm{C}$. The material was then filtered using the cleaned Vivaspin $15 \mathrm{~S}$ ultrafilters, which have a molecular weight cutoff of $30 \mathrm{kD}$ to remove smaller contaminants such as humic acids. The resultant collagen was then freeze-dried.

The prepared collagen was sealed under vacuum in quartz tubes with an excess of copper oxide $(\mathrm{CuO})$ and combusted at $850^{\circ} \mathrm{C}$ to produce carbon dioxide $\left(\mathrm{CO}_{2}\right)$. The $\mathrm{CO}_{2}$ was converted to graphite on an iron catalyst following the zinc reduction method of Slota et al. (1987). Two samples (UBA-8786 and UBA-8789) produced $<1 \mathrm{mg}$ carbon; thus, it was necessary to convert this material to graphite on an iron catalyst using the hydrogen reduction method of Vogel et al. (1987). The graphite was then pressed to produce a "target," which was then subject to AMS dating. Two laboratories were utilized for AMS dating: 10 samples (lab code UB) were dated in the Oxford Radiocarbon Accelerator Unit (ORAU), University of Oxford, while 78 samples (lab code UBA) were analyzed in the ${ }^{14} \mathrm{CHRONO}$ Centre, Queen's University Belfast. The ${ }^{14} \mathrm{C}$ age and 1 standard deviation were calculated using the Libby half-life (5568 yr), following the conventions of Stuiver and Polach (1977). The ${ }^{14} \mathrm{C}$ ages were then corrected for isotopic fractionation using the AMS-measured $\delta^{13} \mathrm{C}$, which accounts for both natural and machine fractionation, and thus is not presented in the tables summarizing our dates. The $\% \mathrm{C}, \% \mathrm{~N}, \delta^{13} \mathrm{C}$, and $\delta^{15} \mathrm{~N}$ were analyzed using an elemental analyzer-isotopic ratio mass spectrometer (EA-IRMS). Following the guidelines of DeNiro (1985), only samples with C: $\mathrm{N}_{\text {atomic }}$ values between 2.9 and 3.6 were included in the study. The stable isotope results will be presented elsewhere and will not be discussed in any detail here. Calibration of the ${ }^{14} \mathrm{C}$ dates was undertaken using CALIB 5.0.2 software (Stuiver et al. 2005) and the IntCal04 calibration curve (Reimer et al. 2004). 


\section{BACKGROUND AND RESULTS}

\section{Afanasievo Culture}

Archaeologists agree that the Afanasievo is the earliest Eneolithic culture in Southern Siberia (e.g. Gryaznov and Vadetskaya 1968:159; Maksimenkov 1975b:49; Kyzlasov 1992:9; Gryaznov 1999: 45). The date for the beginning of the Afanasievo culture in the Yenisey region is still the subject of discussion, but there is a consensus of opinion that it first appeared in the Minusinsk Basin no earlier than in the middle of the 3rd millennium BC (e.g. Gryaznov and Vadetskaya 1968:159; Vinogradov 1982:12; Kyzlasov 1986:242-3) and was followed by the Okunevo culture at the end of the 3rd millennium BC or beginning of the 2nd millennium BC (Zimina 1964:235; Semenov 1987:19; Kyzlasov 1992:9; see Table 2). However, the date for the start of the culture is regarded as a particularly important issue, because it deals with what has been claimed as one of the longest known migrations, i.e. the 2000-km migration of the Yamnaya people (late 3rd millennium BC), or even pre-Yamnaya (Repin; middle of the 3rd millennium BC) culture from the Volga-Ural region to the east, as far as Southern Siberia (Anthony 2007:307-11). The relation between the Afanasievo and Yamnaya cultures is confirmed by burial ritual, material culture (Vadetskaya 1986:22), and even the physical appearance of the populations (Alekseev 1961:380; Alekseev and Gokhman 1984:35).

Table 2 Traditional dating of the Afanasievo culture.

\begin{tabular}{lll}
\hline Source & Beginning & End \\
\hline Zimina 1964 & n/a & beginning 2nd millennium BC \\
Gryaznov and Vadetskaya 1968 & middle 3rd millennium BC & n/a \\
Vinogradov 1982 & middle 3rd millennium BC & n/a \\
Vadetskaya 1986 & 3rd millennium BC & 17th century BC \\
Kyzlasov 1986 & middle 3rd millennium BC & end 3rd millennium BC \\
Semenov 1987 & n/a & beginning 2nd millennium BC \\
\hline
\end{tabular}

Previous ${ }^{14} \mathrm{C}$ dates are available from 9 Afanasievo sites of the Minusinsk Basin: Chernovaya VI, Krasniy Yar I, Letnik VI, Malinoviy Log, Maliye Kopeny II, Sargov Ulus, Sukhanikha, Sukhanikha II, and Vostochnoye. The majority of calibrated ${ }^{14} \mathrm{C}$ dates fall within the period 3700-2230 BC (Appendix 1). Only the sample Le-532 from Chernovaya-VI is somewhat later, calibrated to 23451883 BC. It should be noted, however, that burials of both the Afanasievo and Okunevo cultures were present in the cemetery (Vadetskaya 1986:23). As such, there is a possibility that the sample belongs to the later Okunevo culture. Thus, as has been noted, the ${ }^{14} \mathrm{C}$ dates of the Afanasievo culture "speak for quite an earlier chronological position of this culture" (Görsdorf et al. 2001:1117). However, the dates from the past research are obtained from wood or charcoal, and it is therefore possible that older dates are a product of the "old wood effect" and/or re-use of old timbers. Modern studies (e.g. Panyushkina et al. 2008) that have been more selective about the wood samples used for dating can generally be considered to be more reliable as compared to some older reports.

A total of 7 samples from 2 Afanasievo sites-Afanasieva Gora $(n=4)$ and Karasuk III $(n=3)$ were analyzed as part of the current project. The ${ }^{14} \mathrm{C}$ dates suggest that the sites were rather synchronous. The majority of the calibrated dates range between 2874 and 2469 BC (Table 3; Figure 2) and fall within the ${ }^{14} \mathrm{C}$ range obtained from previous research (Appendix 1). To summarize, the ${ }^{14} \mathrm{C}$ dating evidence is somewhat at odds with the traditional chronology of the culture. The scientific dating evidence would tend to suggest that the Afanasievo culture is some 300-400 yr older in date than indicated by conventional archaeological understanding. 
Table 3 New ${ }^{14} \mathrm{C}$ dates of the Afanasievo samples $(n=7) .{ }^{\mathrm{a}}$

\begin{tabular}{lllc}
\hline Lab ID & Provenance & ${ }^{14}$ C BP & Calibrated age (2 $\sigma)$ \\
\hline UBA-7902 & Afanasieva Gora, burial 71 & $\mathbf{1 2 9 7} \pm \mathbf{2 7}$ & $\mathbf{6 6 3 - 7 7 2}$ cal AD \\
UB-7489 & Afanasieva Gora, burial 73 & $4077 \pm 39$ & $2860-2489$ cal BC \\
UBA-7903 & Afanasieva Gora, burial 73 & $4037 \pm 31$ & $2831-2473$ cal BC \\
UBA-8772 & Afanasieva Gora, burial 75 & $4092 \pm 27$ & $2858-2502$ cal BC \\
UBA-8773 & Karasuk III, enclosure 1, grave 2, skeleton 2 & $3996 \pm 26$ & $2573-2469$ cal BC \\
UBA-8774 & Karasuk III, enclosure 1, grave 3, skeleton 1 & $4148 \pm 26$ & $2874-2630$ cal BC \\
UBA-7904 & Karasuk III, enclosure 7, grave 1, skeleton 1 & $\mathbf{2 3 6 2} \pm \mathbf{2 9}$ & $\mathbf{5 1 8 - 3 8 6}$ cal BC \\
\hline
\end{tabular}

${ }^{\mathrm{a}} \mathrm{Here}$ and further in tables: sharply different ${ }^{14} \mathrm{C}$ dates are highlighted in bold.

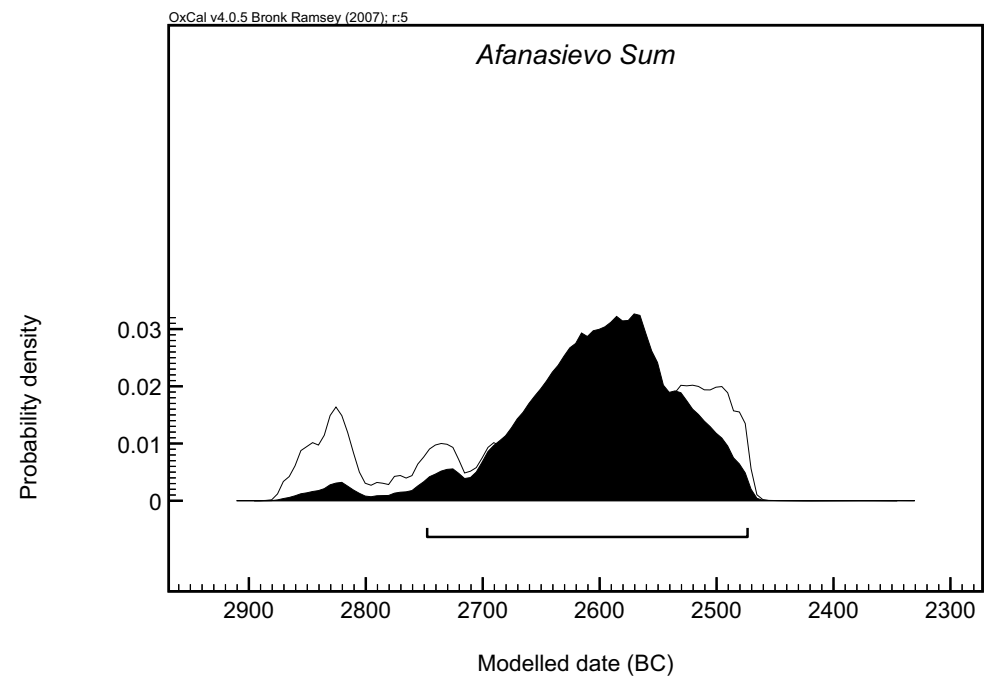

Figure 2 Summed probability distribution for new human bone dates, Afanasievo culture. (This and further OxCal plots were generated using OxCal v4.0.5 software [Bronk Ramsey 1995, 2001] and the IntCal04 calibration curve [Reimer et al. 2004].)

It should be noted that 2 individuals_-UBA-7902 and -7904-provided much more recent dates than other samples from the same sites. It is considered probable that these individuals have been incorrectly ascribed to the Afanasievo culture and rather that they date to the early medieval period and the Tagar culture, respectively. Indeed, examination of the excavation report for Karasuk III revealed that UBA-7904 had derived from an intrusive burial (Gryaznov 1999:36-7). Unfortunately, it was not possible to obtain further information concerning the burial context of the UBA-7902 sample.

The majority of the wood/charcoal dates for Afanasievo are not incompatible with the human bone dates presented here, with the notable exception of $4 \mathrm{wood} / \mathrm{charcoal}$ determinations from Malinoviy Log, which are all considerably earlier, by some $600{ }^{14} \mathrm{C}$ yr. The explanation for this is not clear at the moment, but it seems unlikely that it can be explained entirely as an old-wood effect.

\section{Okunevo Culture}

At the end of the 1940s, the Okunevo culture was defined by Komarova (1947) as a separate early stage of the Andronovo culture. Further excavations, however, revealed that it was a completely distinct culture, which appeared to be younger than the Afanasievo culture and older than the Andronovo culture. It is generally believed that the beginning of the Okunevo culture immediately 
followed the Afanasievo culture. Some scholars have suggested there may have been a gap in time between the end of the Afanasievo and the beginning of the Okunevo (Savinov 1995:4), while others have proposed that the end of the Afanasievo and the beginning of the Okunevo saw a degree of overlap (Khlobystina 1973; Sokolova 2002, 2006).

The end of the Okunevo culture is also poorly understood. Archaeologists have noted that in various regions of the Middle Yenisey region, the Okunevo was replaced by different cultures at different times. It is believed that the Okunevo culture persisted until the Late Bronze Age, when it was replaced by the Karasuk culture, in both the Republic of Tuva and in the south of the Minusinsk Basin (Semenov 1984:253, 1997:157-60; Vadetskaya 1986:36, 46; Molodin 1992:29; Lazaretov 2001:104, 2007:41; Savinov 2002:24, 32). In the northern part of the basin, however, the Okunevo culture appears to have been succeeded by the Andronovo culture no earlier than the 14th-13th centuries BC (Vadetskaya 1986:36; Lazaretov 2007:41). Vadetskaya (1986:36) has suggested the Okunevo culture dates to the 18th-13th centuries BC, thereby corresponding to the dates of other related cultures, such as the Samus (18th-13th centuries BC) and the Krotovo (first half of the 2nd millennium BC to the 13th century BC) cultures of Western Siberia.

Table 4 Traditional dating of the Okunevo culture.

\begin{tabular}{lll}
\hline Source & Beginning & End \\
\hline Gryaznov 1969 & beginning 2nd millennium BC & n/a \\
Maksimenkov 1968b & beginning 2nd millennium BC & middle 2nd millennium BC \\
Maksimenkov 1975a & 21st century BC & 17th century BC \\
Vadetskaya 1986 & 18th-17th centuries BC & 13th-11th centuries BC \\
Kyzlasov 1986 & end 3rd millennium BC & n/a \\
Lazaretov 2007 & turn of the 3rd and 2nd millennia BC & 14th-13th centuries BC \\
\hline
\end{tabular}

As such, it is clear that the chronology of the Okunevo culture is generally poorly understood, although most archaeologists agree that it first appeared in the Minusinsk Basin at the end of the 3rd millennium $\mathrm{BC}$ or the beginning of the 2 nd millennium $\mathrm{BC}$, lasting until the middle of the 2 nd millennium BC (Table 4).

Only 14 previous ${ }^{14} \mathrm{C}$ dates are available from 7 Okunevo sites of the Minusinsk Basin: Chebaki, Chernovaya, Karasuk III, Lebyazhye, Pristan I, Uibat V, and Ust-Kindirla (Appendix 2). When calibrated, the dates belong mostly to the last third of the 3rd to beginning of the 2nd millennia BC (2467-1693 BC). Two dates from Lebyazhye and Uibat V appear to be older outliers, however, belonging to the end of the 4 th to beginning of the $3 \mathrm{rd}$ millennia $\mathrm{BC}$ and middle of the $3 \mathrm{rd}$ millennium BC, respectively. These dates again place the Okunevo culture rather earlier than the traditional chronology would tend to suggest. It should be noted, however, that the discrepancy between ${ }^{14} \mathrm{C}$ and archaeological chronologies is not as large as was the case for the Afanasievo culture.

A total of 19 samples from 5 sites of the Okunevo culture-Bateni $(n=1)$, Okunev Ulus $(n=3)$, Uibat III $(n=1)$, Uibat V $(n=7)$, and Verhniy Askiz I $(n=7)$ - have been dated as part of the current project. The majority of calibrated dates belong to the second half of the 3rd to beginning of the 2nd millennia BC (2565-1885 BC; Table 5, Figure 3), thereby correlating with the previous ${ }^{14} \mathrm{C}$ dating evidence. Only 2 dates (UBA-7920 and -7907) are very much at odds with the general range, belonging to the 1st millennium BC. In both cases, no chronologically diagnostic material was recovered from the graves, and the burials were initially assigned to the Okunevo culture because the whole complex was attributed to the culture. It would appear, however, that the burial from which UBA-7907 was taken may have been intrusive and that it actually belonged to the Tagar culture. Only 2 individuals were recovered from Kurgan 3 at Uibat V (UBA-7920), and it is possible that the entire burial complex belonged to the Karasuk or Tagar culture. 
Table 5 New ${ }^{14} \mathrm{C}$ dates of the Okunevo samples $(n=20)$.

\begin{tabular}{llll}
\hline Lab ID & Provenance & $\begin{array}{l}\text { Age, cal BC } \\
(2 \sigma)\end{array}$ \\
\hline UBA-8771 & Bateni & $3853 \pm 35$ & $2461-2206$ \\
UB-7494 & Okunev Ulus, grave 5 & $3757 \pm 35$ & $2287-2040$ \\
UBA-7927 & Okunev Ulus, grave 5 & $3725 \pm 38$ & $2276-1983$ \\
UBA-7929 & Okunev Ulus, grave 7 & $3619 \pm 40$ & $2131-1885$ \\
UBA-7916 & Uibat III, kurgan 1, grave 1, cranium 1 & $3644 \pm 44$ & $2137-1901$ \\
UBA-7912 & Uibat V, kurgan 1, grave 3 & $3723 \pm 30$ & $2202-2032$ \\
UBA-7917 & Uibat V, kurgan 1, grave 3a Va, skeleton V & $3832 \pm 28$ & $2457-2154$ \\
UBA-7963 & Uibat V, kurgan 2, grave 4, skeleton A & $3691 \pm 26$ & $2193-1980$ \\
UBA-7920 & Uibat V, kurgan 3, skeleton 1 & $\mathbf{2 7 4 0} \pm \mathbf{2 6}$ & $\mathbf{9 6 8 - 8 2 1}$ \\
UBA-7964 & Uibat V, kurgan 4, grave 4, cranium A & $3721 \pm 25$ & $2199-2035$ \\
UBA-7965 & Uibat V, kurgan 4, grave 18 & $3651 \pm 25$ & $2133-1944$ \\
UBA-7915 & Uibat V, kurgan 4, grave 21, skeleton 2 & $3698 \pm 28$ & $2196-1981$ \\
UBA-7910 & Verhniy Askiz I, kurgan 1, grave 6 & $3654 \pm 29$ & $2135-1944$ \\
UBA-7908 & Verhniy Askiz I, kurgan 1, grave 10, skeleton 1 & $3719 \pm 31$ & $2202-2029$ \\
UBA-7914 & Verhniy Askiz I, kurgan 1, grave 13, skeleton 1 & $3894 \pm 28$ & $2467-2297$ \\
UBA-7907 & Verhniy Askiz I, kurgan 1, grave 18 & $\mathbf{2 6 0 9} \pm \mathbf{2 9}$ & $\mathbf{8 2 5 - 6 7 6}$ \\
UBA-7913 & Verhniy Askiz I, kurgan 2, grave 4, skeleton 1 & $3934 \pm 39$ & $2565-2297$ \\
UBA-7919 & Verhniy Askiz I, kurgan 2, grave 15, skeleton 1 (burial 1) & $3738 \pm 30$ & $2273-2035$ \\
UBA-7911 & Verhniy Askiz I, kurgan 2, grave 21, skeleton 1 & $3713 \pm 30$ & $2200-2028$ \\
\hline
\end{tabular}

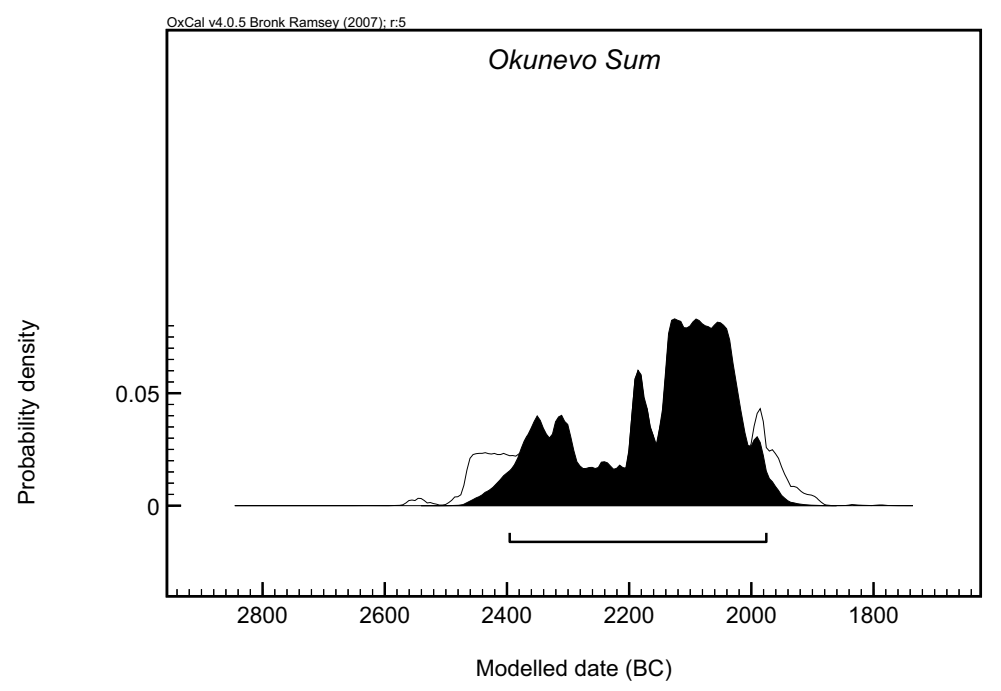

Figure 3 Summed probability distribution for new human bone dates, Okunevo culture

Particular note should be made of the individual recovered from a grave near the former settlement of Bateni, from which sample UBA-8771 derived. On the basis of associated archaeological evidence, this burial was believed to be of Neolithic date-the only Neolithic burial attributed in the territory of the Minusinsk Basin (Gryaznov 1953; Vadetskaya 1986:11). The new ${ }^{14} \mathrm{C}$ date, however, indicates that the burial was actually from the Okunevo culture.

Both previous $(n=7$; lab code Bln $)$ and new $\left(n=6\right.$; lab code UBA) ${ }^{14} \mathrm{C}$ dates obtained from 3 kurgans at the site of Uibat $\mathrm{V}$ are provided in Table 6 . The previous calibrated dates vary between the 
27 th and 19th centuries BC, while the new dates range from the 25th to the 20th centuries BC. As such, the dates are in general agreement.

Table $6{ }^{14} \mathrm{C}$ dates from Uibat V, Okunevo culture $(n=13)$.

\begin{tabular}{lllll} 
Lab ID & Material & Provenance & $\begin{array}{l}\text { Age, cal BC } \\
(2 \sigma)\end{array}$ \\
\hline Bln-5195 & human bone & Uibat V, kurgan 1, grave 1 & $3734 \pm 29$ & $2266-2034$ \\
UBA-7912 & human bone & Uibat V, kurgan 1, grave 3 & $3723 \pm 30$ & $2202-2032$ \\
ID n/a & human bone & Uibat V, kurgan 1, grave 3 & $3830 \pm 25$ & $2456-2153$ \\
UBA-7917 & human bone & Uibat V, kurgan 1, grave 3a Va, skeleton V & $3832 \pm 28$ & $2457-2154$ \\
Bln-5196 & human bone & Uibat V, kurgan 1, grave 4 & $4016 \pm 30$ & $2618-2470$ \\
UBA-7963 & human bone & Uibat V, kurgan 2, grave 4, skeleton A & $3691 \pm 26$ & $2193-1980$ \\
UBA-7964 & human bone & Uibat V, kurgan 4, grave 4, cranium A & $3721 \pm 25$ & $2199-2035$ \\
Bln-4951 & bone & Uibat V, kurgan 4, grave 4 & $3631 \pm 41$ & $2134-1891$ \\
Bln-4762 & wood & Uibat V, kurgan 4, grave 5 & $3782 \pm 62$ & $2457-2033$ \\
Bln-4950 & bone & Uibat V, kurgan 4, grave 15 & $3620 \pm 35$ & $2125-1890$ \\
UBA-7965 & human bone & Uibat V, kurgan 4, grave 18 & $3651 \pm 25$ & $2133-1944$ \\
Bln-4949 & bone & Uibat V, kurgan 4, grave 20 & $3657 \pm 43$ & $2192-1916$ \\
UBA-7915 & human bone & Uibat V, kurgan 4, grave 21, skeleton 2 & $3698 \pm 28$ & $2196-1981$ \\
\hline
\end{tabular}

${ }^{a}$ The source (Lazaretov 1995) specifies that the date was obtained in the Heidelberg Radiocarbon Laboratory.

\section{Andronovo Culture}

The Andronovo (Fedorovo) culture of the Middle Yenisey represented a branch, or an eastern limit, of a large Andronovo "cultural-historical unit," which was spread over a vast territory, including Western Siberia, Central Asia, the steppe zone of Siberia, Southern Siberia, eastern Kazakhstan, and northern China (Martynov 1964:250; Gryaznov 1969:89; Khavrin 1992). Throughout the text, the term "Andronovo culture" is applied to the sites of the Minusinsk Basin.

Archaeologists have different views concerning the beginning of the Andronovo culture in the Minusinsk Basin (Table 7). The archaeological information on which these views are based includes the spread of Andronovo (Fedorovo) ceramics in Western Siberia (Maksimenkov 1968a:179-80) and the sequence and morphology of burials, particularly their structure, in multicultural cemeteries (Vadetskaya 1986:46).

Table 7 Traditional dating of the Andronovo culture.

\begin{tabular}{lll}
\hline Source & Beginning & End \\
\hline Kiselev 1951 & 17th-16th centuries BC & n/a \\
Maksimenkov 1968a & 16th-14th centuries BC & n/a \\
Vadetskaya 1986 & 13th century BC & 11th century BC \\
Kyzlasov 1992 & 16th century BC & 14th century BC \\
Kuzmina 2007 & 15th-14th centuries BC & 13th century BC \\
\hline
\end{tabular}

Different opinions also exist concerning the duration of the Andronovo culture in the Minusinsk Basin (Table 7). Vadetskaya (1986:46) proposed that the culture lasted for different lengths of time in different parts of the basin, persisting for longer in the north than in the central part of the region. In the southern part of the basin, the preceding Okunevo culture is considered to have been replaced directly by the Karasuk culture, since no evidence of the Andronovo culture has, as yet, been discovered there (Molodin 1992:29; Lazaretov 2001:104; Bobrov 2003:14; Savinov 2005:29). 
The range of ${ }^{14} \mathrm{C}$ dates available for the Andronovo culture is very broad (Appendix 3). There is no clear explanation for this diversity of dates; although it is probable that the 3 youngest dates (Le-529, -518 , and -595) might indicate the presence of later intrusive burials from the Karasuk and Tagar cultures in large Andronovo culture cemeteries. Dates obtained from the cemetery of Potroshilovo II suggest the first third of the $2 \mathrm{nd}$ millennium $\mathrm{BC}$ as the time of transition between the Okunevo and Andronovo cultures, and the middle of the 2nd millennium $\mathrm{BC}$ as the time of transition between the Andronovo culture and the "Classical" phase of the Karasuk culture (Görsdorf et al. 2001:1117).

The 9 new dates provided by the current study and obtained from 4 Andronovo sites-Pervomayskoye I ( $n=1)$, Potroshilovo II $(n=2)$, Ust-Bir I $(n=3)$, and Yarki II $(n=3)$-are very similar. They all belong to the 18 th -15 th centuries BC $(1744-1500$ cal BC; Table 8, Figure 4$)$. The new ${ }^{14} \mathrm{C}$ dates correlate well with the majority of dates obtained previously ( 9 dates from the $21 \mathrm{st}-15$ th centuries $\mathrm{BC}$ ); however, they are again slightly older than the traditionally accepted archaeological chronology. It is also worth noting that the new dates obtained from Potroshilovo II correlate well with previous ${ }^{14} \mathrm{C}$ dates derived from the site and also obtained from human bone (Appendix 3 ).

Table 8 New ${ }^{14} \mathrm{C}$ dates of the Andronovo samples $(n=9)$.

\begin{tabular}{llll}
\hline Lab ID & Provenance & $\begin{array}{l}\text { Age, cal BC } \\
(2 \sigma)\end{array}$ \\
\hline UBA-7922 $^{\text {a }}$ & Pervomayskoye I, grave 28 & $3205 \pm 41$ & $1606-1407$ \\
UBA-9328 & Potroshilovo II, enclosure 5, grave 3 & $3294 \pm 28$ & $1657-1500$ \\
UBA-9329 & Potroshilovo II, enclosure 15 & $3316 \pm 24$ & $1667-1523$ \\
UBA-9331 & Ust-Bir I, grave 16 & $3382 \pm 27$ & $1744-1617$ \\
UBA-9332 & Ust-Bir I, grave 19 & $3278 \pm 23$ & $1614-1500$ \\
UBA-9333 & Ust-Bir I, grave 26 & $3309 \pm 22$ & $1661-1520$ \\
UB-7491 & Yarki II, grave 1 & $3317 \pm 34$ & $1686-1516$ \\
UB-7490 & Yarki II, grave 2 & $3333 \pm 35$ & $1730-1522$ \\
UBA-7921 & Yarki II & $3348 \pm 32$ & $1735-1530$ \\
\hline
\end{tabular}

aThe site is commonly attributed to the "Classical" Karasuk culture (Vadetskaya 1986:66); however, a detailed analysis of artifacts recovered from the graveyard suggests the attribution of several graves (including grave 28) to the earlier Andronovo culture.

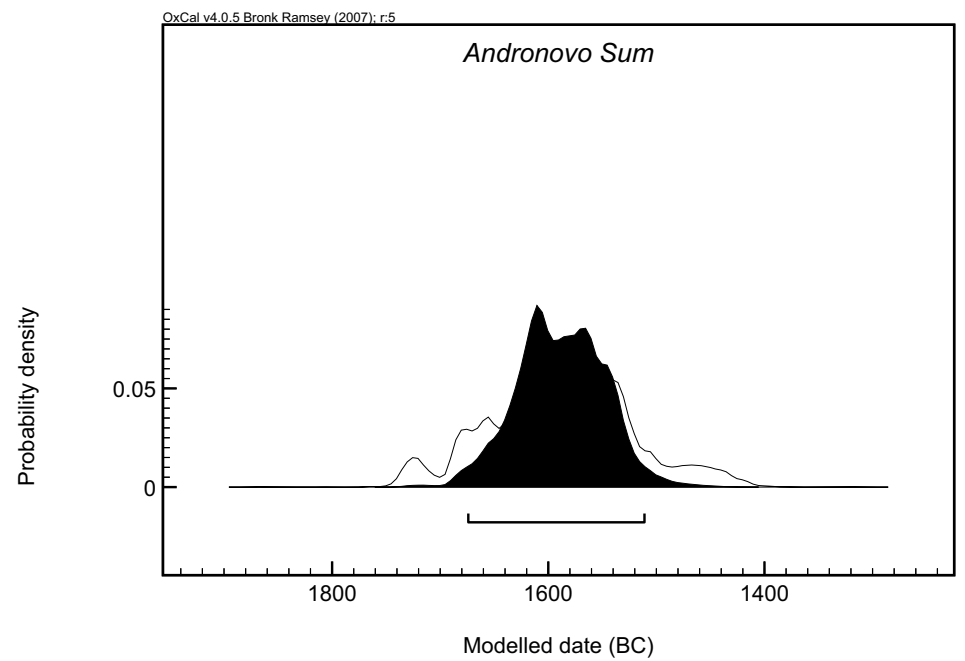

Figure 4 Summed probability distribution for new human bone dates, Andronovo culture 


\section{Karasuk Culture}

Archaeological dating of the Karasuk culture is mainly based on the similarity of knives particular to this culture with those found to the east of the Minusinsk Basin, including northern China (Vadetskaya 1986:64). The archaeological dating also finds support through comparison with similar cultures and archaeological complexes in Western Siberia where Karasuk artifacts have also been recovered (e.g. Irmen culture of Baraba or Yelovo culture of the Ob region; Vadetskaya 1986:64). Table 9 presents the main archaeological dates of the culture.

Table 9 Archaeological dating of the Karasuk culture.

\begin{tabular}{lll}
\hline Source & Beginning & End \\
\hline Kiselev 1951 & 12th century BC & 8th century BC \\
Gryaznov et al. 1968 & 13th century BC & 10th century BC \\
Gryaznov 1969 & 13th century BC & 8th century BC \\
Chlenova 1972 & 14th/13th century BC & 7th/6th century BC \\
Vadetskaya 1986 & 11th-10th centuries BC & 8th century BC \\
Kyzlasov 1992 & 13th century BC & 8th century BC \\
Polyakov 2006 & 13th century BC & 9th century BC \\
\hline
\end{tabular}

On the basis of burial type, archaeologists have identified 2 phases of the Karasuk culture, the proper Karasuk phase ("Classical" period) and the Kamenniy Log phase (Late Karasuk or Lugavskaya culture). According to Gryaznov (1969:101), these phases are dated to the 13th-11th centuries BC and 10th-8th centuries BC, respectively. More recent research has also indicated the presence of further subdivisions within these 2 phases (Lazaretov 2006; Polyakov 2006).

Debate has arisen, however, concerning the chronological position of the Kamenniy Log phase, with some archaeologists asking if the phase belonged to the early or late Karasuk period, or even to the transition to the early Tagar culture (Leontyev et al. 1996). This issue has been raised again after 5 ${ }^{14} \mathrm{C}$ dates obtained from the Kamenniy Log site of Sukhanikha surprisingly proved to belong to the last 2 centuries of the 2 nd millennium BC. ${ }^{14} \mathrm{C}$ dating therefore indicated that "Classical" Karasuk and Kamenniy Log cemeteries were almost contemporaneous during the last 3 or 4 centuries of the 2nd millennium BC. The ${ }^{14} \mathrm{C}$ dates raised the possibility that "Classical" Karasuk and Kamenniy Log phases of the Karasuk culture should be regarded as 2 different cultures that coexisted in the Minusinsk Basin (Görsdorf et al. 2001; also see below).

${ }^{14} \mathrm{C}$ dates for the "Classical" phase of the Karasuk culture have been obtained from 8 sites, including Anchil-Chon, Georgievskiy Kurgan (Tes), Itkol I, Potroshilovo, Sukhanikha I, Sukhanikha, TertAba, and Torgajak. Most of these sites belong to the 14th-10th centuries BC (Appendix 4). The youngest dates, derived from Anchil-Chon (11th-5th centuries BC) and Torgajak (9th-5th centuries BC), are explained as either evidence for the existence of later burials (Alekseev et al. 2005:106) or by insufficiency or deterioration of the sample (Alekseev et al. 2005:108).

${ }^{14} \mathrm{C}$ dates for the Kamenniy Log phase of the Karasuk culture have also been obtained from 8 sites: Anchil-Chon, Kamenniy Ostrov, Dolgiy Kurgan, Karasuk IV, Kolok, Kuten-Buluk, Sukhanikha, and Uij. The majority of calibrated dates belong to the 14th/13th-9th centuries BC, although a number of samples from Karasuk IV, Sukhanikha, and Sukhanikha (Podsukhanikha) II appear to be older and date to the 15th-10th centuries BC (Appendix 4). It is interesting to note that all older dates for the culture were derived from wood, birch bark, or charcoal, and could, therefore, reflect the oldwood effect, or represent the re-use of old timbers. 
Nevertheless, current understanding of the chronology of the Karasuk culture derived from previous ${ }^{14} \mathrm{C}$ dates suggests the following scheme for the dating of the 2 phases (Alekseev et al. 2005:222-3):

- "Classic" Karasuk phase: 15th-10th centuries BC for the southern part of the Minusinsk Basin (minor Minusinsk Basin; no data available from the northern part).

- Kamenniy Log phase: 10th-9th centuries BC for the southern part and 12th-9th centuries BC for the northern part of the Minusinsk Basin.

The ${ }^{14} \mathrm{C}$ dates obtained during previous research have therefore demonstrated a tendency to provide an older chronology for the Karasuk culture and to disagree with the archaeological evidence that has been used to suggest younger dating (e.g. Chlenova 1972; Vadetskaya 1986).

Some 19 samples from the Karasuk culture were dated for this project. These derived from 6 "Classic" Karasuk sites $(n=16)$, a transitional Karasuk-Kamenniy Log site $(n=1)$, and 2 Kamenniy Log phase sites $(n=2)$. The majority of calibrated dates from the "Classic" Karasuk phase belonged to the 14th-10th centuries BC, while those from the Kamenniy Log Phase varied between the 12th and 9 th centuries BC (Table 10, Figure 5). The dates agree with the ${ }^{14} \mathrm{C}$ dates obtained from previous research, but are slightly older (some 100-200 yr) than the proposed archaeological dating of the culture. The new ${ }^{14} \mathrm{C}$ data suggests that the site of Pervomayskoye $\mathrm{I}$ is around 1 to 4 centuries older than the remainder of the "Classic" Karasuk phase sites analyzed, although this may simply be due to the fact that only 1 burial was dated from this cemetery. Three dates from the "Classic" Karasuk phase (UBA-8778, -7492, and -8782) were notably younger than the other dates. These burials appear to be intrusive, however, and possibly belong to the later Tagar culture. The ${ }^{14} \mathrm{C}$ date obtained for UBA-8781 was considerably older than the remainder of the samples. The archaeological report noted that no chronologically diagnostic material was recovered from the burial. Okunev Ulus is a complicated multiperiod cemetery, and it would seem possible that this anomalous burial belongs to the earlier Okunevo culture.

Table 10 New ${ }^{14} \mathrm{C}$ dates of the Karasuk samples $(n=19)$.

\begin{tabular}{|c|c|c|c|}
\hline Lab ID & Provenance & ${ }^{14} \mathrm{C} \mathrm{BP}$ & $\begin{array}{l}\text { Age, cal BC } \\
(2 \sigma)\end{array}$ \\
\hline \multicolumn{4}{|c|}{ Karasuk phase $(n=17)$} \\
\hline UBA-7932 & Karasuk I, grave 65 & $2957 \pm 45$ & $1367-1018$ \\
\hline UBA-7933 & Karasuk I, grave 65 & $2978 \pm 39$ & $1372-1056$ \\
\hline UBA-9327a & Minusinsk Karyer & $3008 \pm 22$ & $1375-1132$ \\
\hline UBA-8779 & Okunev Ulus, grave 2 & $2962 \pm 24$ & $1293-1060$ \\
\hline UBA-9338 & Okunev Ulus, grave 2 & $2890 \pm 27$ & $1194-980$ \\
\hline UBA-7928 & Okunev Ulus, grave 5 & $2987 \pm 55$ & $1388-1052$ \\
\hline UBA-8781 & Okunev Ulus, grave 5 & $3687 \pm 25$ & 2191-1979 \\
\hline UBA-8778 & Okunev Ulus, grave 12 & $2685 \pm 27$ & 896-804 \\
\hline UBA-7925 & Pervomayskoye I, grave 21 & $3122 \pm 42$ & $1494-1300$ \\
\hline UBA-9339 & Podgornoye Ozero I, grave 3 & $3021 \pm 27$ & $1388-1134$ \\
\hline UBA-8777 & Podgornoye Ozero I, grave 4 & $3063 \pm 24$ & $1406-1268$ \\
\hline UB-7492 & Podgornoye Ozero I, grave 5 & $2548 \pm 33$ & $801-546$ \\
\hline UBA-7923 & Podgornoye Ozero I, grave 6 & $3017 \pm 41$ & $1393-1129$ \\
\hline UBA-7924 & Podgornoye Ozero I, grave 8 & $2850 \pm 41$ & $1188-905$ \\
\hline UB-7493 & Yarki I, grave 1 (35) & $2945 \pm 33$ & $1287-1029$ \\
\hline UBA-7930 & Yarki I, grave 3 (37) & $2904 \pm 40$ & $1258-977$ \\
\hline UBA-8782 & Yarki I, grave 4 & $2200 \pm 31$ & 376-191 \\
\hline \multicolumn{4}{|c|}{ Kamenniy Log phase $(n=2)$} \\
\hline UBA-7966 & Kamenniy Ostrov, excavation 1 & $2833 \pm 24$ & $1053-913$ \\
\hline UBA-7931 & Solonechniy Log, grave 1 (16) & $2793 \pm 78$ & $1192-804$ \\
\hline
\end{tabular}

aThe sample is archaeologically dated to the transition between the Karasuk and Kamenniy Log phases of the culture. 


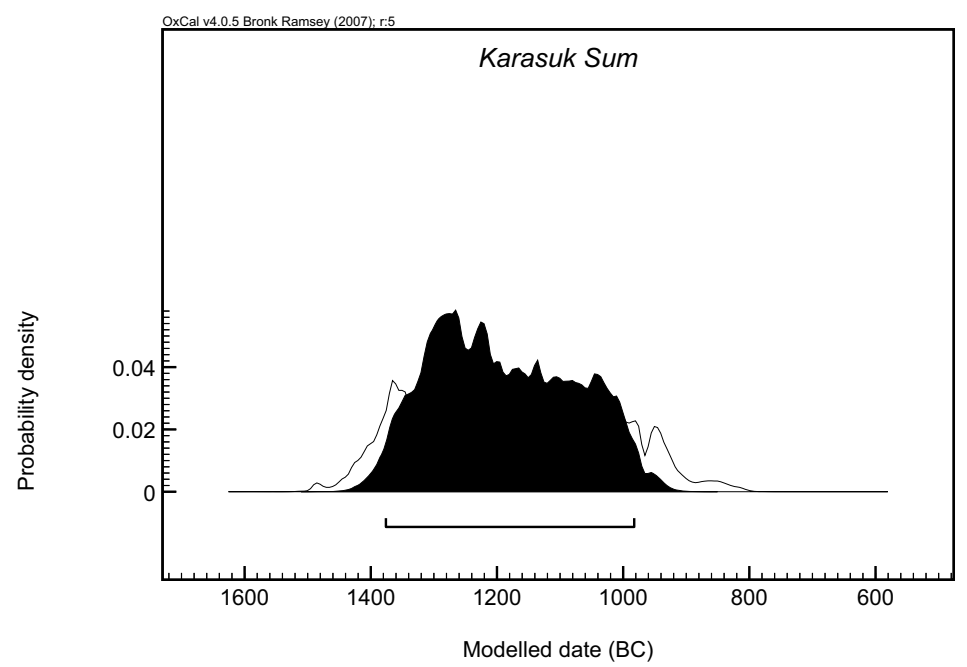

Figure 5 Summed probability distribution for new human bone dates, Karasuk culture

The date of 1053-913 cal BC for UBA-7966 (Kamenniy Ostrov) in Table 10 is in a good agreement with that of 1017-829 cal BC for Ua-24153 from the same site.

\section{Tagar Culture}

On the basis of archaeological data, including the development of burial structures, funerary ceremonies, and artifacts, the Tagar culture has been divided into 4 phases. These were first proposed by Gryaznov (1969:214) during the late 1960s: Bainovo, Podgornovo, Saragash, and Tes phases (Table 11).

Table 11 Archaeological periodization of the Tagar culture.

\begin{tabular}{|c|c|c|c|c|}
\hline Source & Bainovo phase & Podgornovo phase & Saragash phase & Tes phase \\
\hline Kiselev 1951 & from 7 th century $\mathrm{BC}$ & $\mathrm{n} / \mathrm{a}$ & $\mathrm{n} / \mathrm{a}$ & $\mathrm{n} / \mathrm{a}$ \\
\hline Gryaznov 1969 & 7th-6th centuries BC & 6 th-5th centuries BC & 4th-3rd centuries BC & 2 nd- 1 st centuries BC \\
\hline Chlenova 1972 & from 7 th century $\mathrm{BC}$ & $\mathrm{n} / \mathrm{a}$ & $\mathrm{n} / \mathrm{a}$ & $\mathrm{n} / \mathrm{a}$ \\
\hline Vadetskaya 1986 & from 7 th century $\mathrm{BC}$ & $\mathrm{n} / \mathrm{a}$ & $\mathrm{n} / \mathrm{a}$ & $\begin{array}{l}\text { 2nd century BC- } \\
\text { 1st century AD }\end{array}$ \\
\hline Bokovenko 2006 & $\begin{array}{l}\text { end of 10th- } \\
\text { 8th centuries BC }\end{array}$ & 8th-6th centuries BC & 6th-3rd centuries BC & $\begin{array}{l}\text { 2nd-1st centuries BC } \\
\text { or } 1 \text { st century AD }\end{array}$ \\
\hline
\end{tabular}

A substantial number of ${ }^{14} \mathrm{C}$ dates are available for the 4 phases of the Tagar culture (Appendix 5). On the basis of ${ }^{14} \mathrm{C}$ dating, it is generally believed that the transition between the Kamenniy Log phase of the Karasuk culture and the earliest Tagar culture took place during the 9th century BC at the latest (Görsdorf et al. 2001:1118). The position of the Bainovo, Podgornovo, and Saragash stages of the culture appears to have ranged from the 10th century BC to the 1st century AD (Table 12). Most ${ }^{14} \mathrm{C}$ dates of the Tes phase belong to the 2 nd -4 th centuries $\mathrm{AD}$. Overall, the ${ }^{14} \mathrm{C}$ dates obtained previously for the Tagar culture are slightly older than the traditional chronology.

Table 12 Periodization of the Tagar culture based on ${ }^{14} \mathrm{C}$ data (after Alekseev et al. 2005:222-4).

\begin{tabular}{llll}
\hline Area of the Minusinsk Basin & Bainovo phase & Podgornovo phase & Saragash phase \\
\hline Southern part & beg.-mid 9th cent. BC & 9th-7th cent. BC & end 9th-3rd cent. BC \\
Central part & n/a & 9th-8th cent. BC & 8th-5th cent. BC \\
Northern part & 9th cent. BC & 9th-beg. 7th cent. BC & end 9th-5th cent. BC \\
\hline
\end{tabular}


New ${ }^{14} \mathrm{C}$ dates were derived from a total of 34 Tagar individuals, from 9 archaeological sites that represented the Podgornovo, Saragash, and Tes phases of the culture. In general, the calibrated dates belong to the 9th century BC to 2nd century AD (Table 13, Figure 6). Samples from the Podgornovo phase sites date mostly to the 9th-6th/5th centuries BC, while those derived from Saragash phase sites date to the 8th-5th centuries BC, and those from Tes phase sites to the 2nd century BC to 2nd century AD. The new ${ }^{14} \mathrm{C}$ dates generally correspond with the dates available from previous studies, although it should be noted that the lower range of the Podgornovo phase dates were 2-3 centuries younger (Table 12).

Table 13 New ${ }^{14} \mathrm{C}$ dates of the Tagar samples $(n=34)$.

\begin{tabular}{|c|c|c|c|}
\hline Lab ID & Provenance & ${ }^{14} \mathrm{C} \mathrm{BP}$ & $\begin{array}{l}\text { Calibrated age range } \\
(2 \sigma)\end{array}$ \\
\hline \multicolumn{4}{|c|}{ Phase not determined $(n=2)$} \\
\hline UBA-7951 & Melnichniy Log - Barsuchinniy Log, grave 35 & $2366 \pm 28$ & $519-388 \mathrm{cal} \mathrm{BC}$ \\
\hline UBA-7952 & Melnichniy Log - Barsuchinniy Log, grave 37 & $2483 \pm 32$ & $771-417 \mathrm{cal} \mathrm{BC}$ \\
\hline \multicolumn{4}{|c|}{ Podgornovo phase $(n=16)$} \\
\hline UBA-7960 & Grishkin Log I, kurgan 1, grave 17 (28) & $2539 \pm 24$ & $795-551$ cal BC \\
\hline UBA-7935 & Grishkin Log I, kurgan 2, grave 18 (29) & $2653 \pm 49$ & 914-768 cal BC \\
\hline UBA-7936 & Nurilkov Ulus, grave 2 & $2332 \pm 39$ & $520-233 \mathrm{cal} \mathrm{BC}$ \\
\hline UBA-8784 & Nurilkov Ulus, grave 2 & $2414 \pm 21$ & $726-404$ cal BC \\
\hline UBA-8785 & Nurilkov Ulus, grave 2 & $2485 \pm 21$ & $765-520 \mathrm{cal} \mathrm{BC}$ \\
\hline UBA-8786 & Podgornoye Ozero, grave 1 (10), burial 10a & $2166 \pm 43$ & 370-93 cal BC \\
\hline UBA-8787a & Podgornoye Ozero, grave 3 & $2348 \pm 22$ & $503-383$ cal BC \\
\hline UBA-9335a & Podgornoye Ozero, grave 7 & $2630 \pm 24$ & $829-787$ cal BC \\
\hline UB-7496 & Podgornoye Ozero, kurgan 1, grave 17 & $2561 \pm 34$ & $805-549$ cal BC \\
\hline UBA-7939a & Podgornoye Ozero, kurgan 3 , from the mound & $2356 \pm 39$ & $727-369$ cal BC \\
\hline UBA-8788 & Podgornoye Ozero, kurgan 3 , grave 22 & $3011 \pm 22$ & 1378-1133 cal BC \\
\hline UBA-8789a & Podgornoye Ozero, kurgan 3, grave 22 (northeastern) & $2563 \pm 21$ & $802-596$ cal BC \\
\hline UBA-7941 & Saragash Ozero, grave 13 & $2562 \pm 39$ & $809-544$ cal BC \\
\hline UBA-7940 & Saragash Ozero, grave 14 & $2510 \pm 53$ & $795-417$ cal BC \\
\hline UB-7498 & Yarki II, grave 25 & $2696 \pm 34$ & $906-803$ cal BC \\
\hline UBA-7950 & Yarki II, grave 25 & $2511 \pm 28$ & $787-539 \mathrm{cal} \mathrm{BC}$ \\
\hline \multicolumn{4}{|c|}{ Saragash phase $(n=13)$} \\
\hline UBA-7947b & Lepeshkina, grave 16 & $2342 \pm 29$ & $510-376$ cal BC \\
\hline UBA-8783 & Okunev Ulus, grave 1 & $3894 \pm 24$ & $2466-2299$ cal BC \\
\hline UBA-7946 & Okunev Ulus, kurgan 11 & $2552 \pm 29$ & $800-551 \mathrm{cal} \mathrm{BC}$ \\
\hline UBA-8793 & Okunev Ulus, kurgan 11 & $2476 \pm 19$ & $764-428$ cal BC \\
\hline UBA-9336 & Okunev Ulus, kurgan 11 & $2516 \pm 31$ & $791-539$ cal BC \\
\hline UBA-9337 & Okunev Ulus, kurgan 11 & $2316 \pm 30$ & $412-234$ cal BC \\
\hline UB-7497 & Saragash Ozero, from the mound of the grave 8 & $2486 \pm 38$ & $774-416$ cal BC \\
\hline UBA-7943 & Saragash Ozero, kurgan 1, grave 9 & $2421 \pm 45$ & $753-399$ cal BC \\
\hline UBA-7945 & Saragash Ozero, kurgan 1, grave 10 & $2456 \pm 39$ & 756-411 cal BC \\
\hline UBA-8790 & Saragash Ozero, kurgan 1, grave 9 & $2502 \pm 21$ & $774-539$ cal BC \\
\hline UBA-8791 & Saragash Ozero, kurgan 1, grave 9 & $2478 \pm 21$ & $765-426$ cal BC \\
\hline UBA-8792 & Saragash Ozero, kurgan 1, grave 9 & $2454 \pm 19$ & $751-413$ cal BC \\
\hline UBA-9334 & Saragash Ozero, kurgan 1, grave 9 & $2454 \pm 23$ & $752-412$ cal BC \\
\hline \multicolumn{4}{|c|}{ Tes phase $(n=3)$} \\
\hline UB-7495 & Chernoye Ozero I, kurgan 3 , grave 7 , skeleton 5 & $2080 \pm 33$ & 194-2 cal BC \\
\hline UBA-7948 & Chernoye Ozero I, kurgan 3, grave 35 & $2000 \pm 39$ & 107 cal BC-cal AD 81 \\
\hline UBA-7949 & Chernoye Ozero I, timber, right & $1960 \pm 28$ & $39 \mathrm{cal} \mathrm{BC}-\mathrm{cal}$ AD 119 \\
\hline
\end{tabular}

${ }^{\text {a }}$ The site contains burials of both Podgornovo and Saragash phases. The dates may belong to the Saragash phase.

${ }^{\mathrm{b}}$ The sample is archaeologically dated to the transition between the Saragash and Tes phases of the culture. 


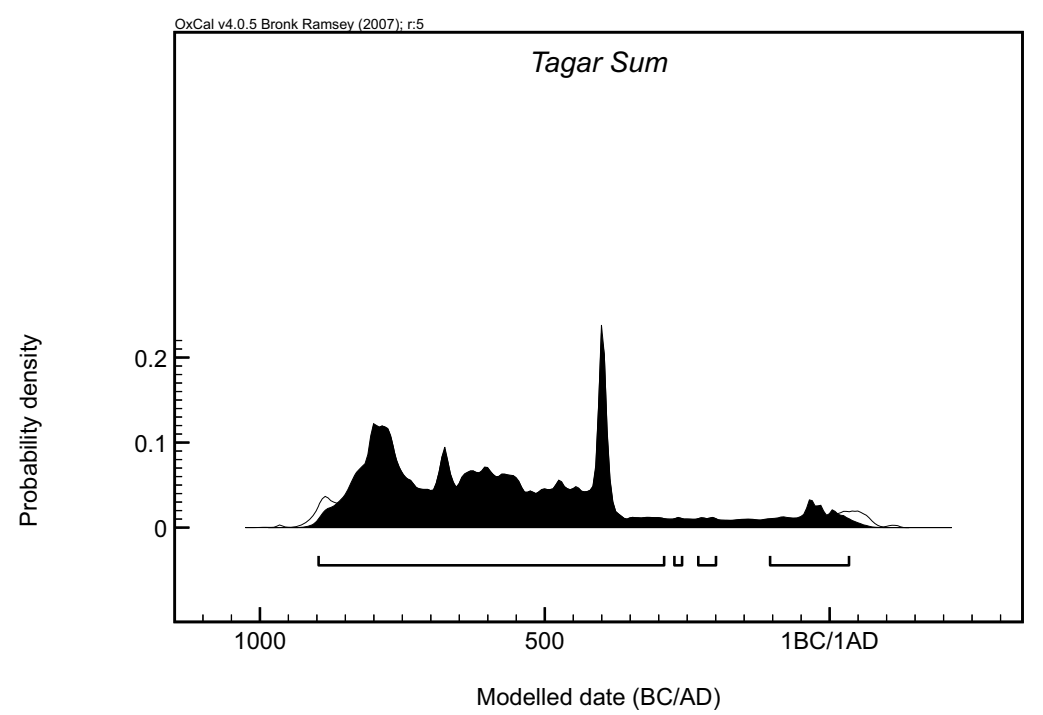

Figure 6 Summed probability distribution for new human bone dates, Tagar culture

The ${ }^{14} \mathrm{C}$ dates UBA-8787 and UBA-8786 from the Podgornoye Ozero site are younger than the rest of the dates of the Podgornovo phase. No further information is available for these burials, but the results suggest that the individuals belong to the later phases of the Tagar culture.

UBA-8788 from Podgornoye Ozero is considerably older than the remainder of the apparently Tagar culture individuals analyzed and, on strictly chronological grounds, places the individual in the Karasuk culture. According to the archaeological data, the graveyard was used over a considerable period of time from the Karasuk through to the later Tagar culture (Podgornovo and Saragash phases; Vadetskaya 1986:66, 117), which also supports the attribution of the anomalous dates derived from Podgornoye Ozero to the earlier Karasuk culture.

UBA-8783 from Okunev Ulus is also considerably older than the remainder of the Tagar culture individuals analyzed. As we have already noted, Okunev Ulus is a complicated multiperiod cemetery, and it is possible that the burial belonged to the earlier Okunevo culture.

\section{DISCUSSION AND CONCLUSIONS}

The current study has involved a review of the chronological evidence for the prehistoric cultures of the Minusinsk Basin of Southern Siberia. The research has also involved new ${ }^{14} \mathrm{C}$ dates obtained from human skeletons from the Afanasievo to Tagar cultures from the region. In general, the research has confirmed the periodization of the Afanasievo to Tagar cultures, first proposed by Teploukhov (1929) and further developed by Gryaznov and other scholars. The main findings can be summarized as follows:

1. The new ${ }^{14} \mathrm{C}$ dates suggest the following time frames for the different cultures (Table 14, Figure 7, Table 15; for comparison, time frames obtained from previous ${ }^{14} \mathrm{C}$ research are also included in Table 14).

Overall, the new, improved dating that we are now proposing for the different cultures correspond with ${ }^{14} \mathrm{C}$ dates obtained during past research. 
Table $14{ }^{14} \mathrm{C}$ dates of the Afanasievo to Tagar cultures.

\begin{tabular}{lll}
\hline Culture & Current research & Past research \\
\hline Afanasievo & 29th-25th centuries BC & 37th-25th centuries BC \\
Okunev & 25th-20th centuries BC & 25th-19th centuries BC \\
Andronovo & 18th-16th/15th centuries BC & 19th-15th centuries BC \\
Karasuk, Karasuk phase & 14th-10th centuries BC & 15th-10th centuries BC \\
Kamenniy Log phase & 11th-9th centuries BC & 14th/13th-9th centuries BC \\
Tagar, Bainovo phase & n/a & 9th century BC \\
Podgornovo phase & 9th-6th/5th centuries BC & 9th-7th centuries BC \\
Saragash phase & 8th-5th centuries BC & end 9th-3rd centuries BC \\
Tes phase & 2nd century BC-2nd century AD & 2nd century BC-4th century AD \\
\hline
\end{tabular}

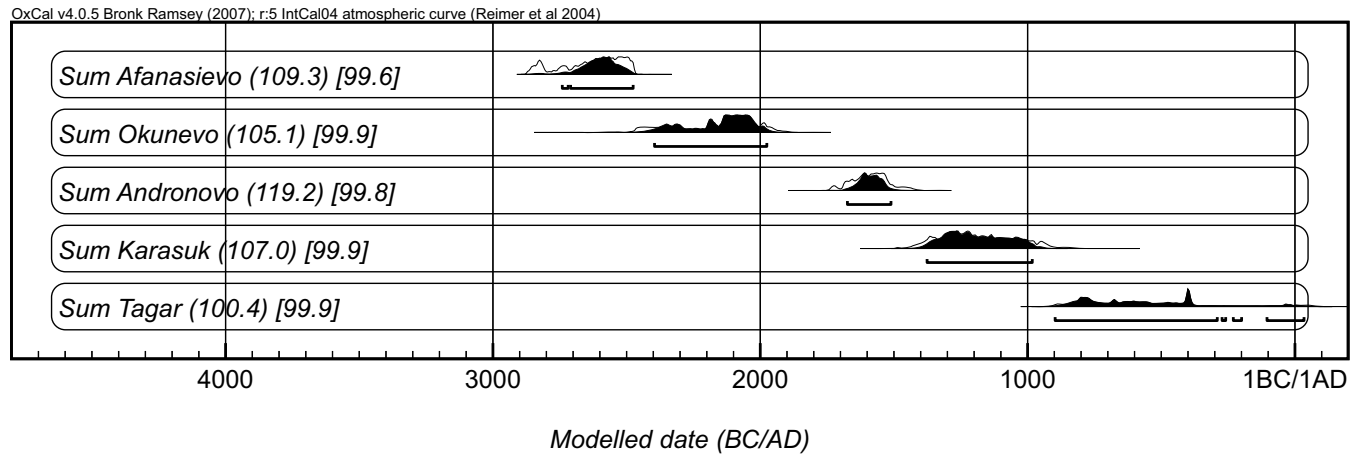

Figure 7 Summed probability distribution for new human bone dates, Afanasievo-Tagar cultures

Table 15 Modeled "start" and "end" dates for the 5 Minusinsk Basin cultures based on the 88 new AMS dates reported here (OxCal 4.0). All transitions except for Okunevo to Andronovo (145-yr gap) show a period of overlap.

\begin{tabular}{lrrrrrr}
\hline Culture & \multicolumn{1}{c}{$n$} & \multicolumn{2}{c}{ "Start" date $(2 \sigma)$} & \multicolumn{2}{c}{ "End" date $(2 \sigma)$} & Overlap \\
\hline Afanasievo & 5 & $2916 \mathrm{BC}$ & $2583 \mathrm{BC}$ & $2575 \mathrm{BC}$ & $2402 \mathrm{BC}$ & - \\
Okunevo & 19 & $2486 \mathrm{BC}$ & $2318 \mathrm{BC}$ & $2055 \mathrm{BC}$ & $1887 \mathrm{BC}$ & 84 \\
Andronovo & 9 & $1742 \mathrm{BC}$ & $1549 \mathrm{BC}$ & $1608 \mathrm{BC}$ & $1440 \mathrm{BC}$ & -145 \\
Karasuk & 16 & $1470 \mathrm{BC}$ & $1300 \mathrm{BC}$ & $1069 \mathrm{BC}$ & $893 \mathrm{BC}$ & 30 \\
Tagar & 38 & $949 \mathrm{BC}$ & $834 \mathrm{BC}$ & $40 \mathrm{BC}$ & AD 104 & 56 \\
\hline
\end{tabular}

2. The sites analyzed during this research may be attributed to the following periods (Table 16; periods obtained from previous research are noted in brackets where applicable).

3. The earliest dates obtained for the Afanasievo culture belong to the 29th-25th centuries cal BC and, therefore, do not correspond with the earliest dates of the culture obtained from previous research (37th-25th centuries cal BC). It is important to specify again here that all previous Afanasievo dates of the Minusinsk Basin belonging to the 4th millennium cal BC were taken from wood or charcoal samples and are thus at risk of providing misleading results due to the old-wood effect (though wood samples from the kurgans of the Early Scythian time from Altai region suggest that trees, mostly larch, no older than $200 \mathrm{yr}$ were used for the burial constructions: Mallory et al. 2002). None of the human skeletons analyzed during the current research are dated earlier than the 29th century cal BC. Thus, most of the bone dates reported here, and wood and charcoal dates from the literature, are in agreement in placing the start of the Afanasievo culture around $3000 \mathrm{BC}$, although we need to keep in mind that as yet only a small sam- 
Table 16 Afanasievo-Tagar sites time frames, based on new ${ }^{14} \mathrm{C}$ data.

\begin{tabular}{|c|c|c|}
\hline Culture & Site & Period \\
\hline \multirow[t]{2}{*}{ Afanasievo culture } & Afanasieva Gora & 29th-25th centuries BC \\
\hline & Karasuk III & 29th-25th centuries BC \\
\hline \multirow[t]{4}{*}{ Okunevo culture } & Okunev Ulus & 23rd-20th centuries BC \\
\hline & Uibat III & $\begin{array}{l}\text { 22nd-20th centuries BC } \\
\text { (26th-20th centuries BC) }\end{array}$ \\
\hline & Uibat V & 24th-20th centuries BC \\
\hline & Verhniy Askiz I & 26th-20th centuries BC \\
\hline \multirow[t]{4}{*}{ Andronovo culture } & Potroshilovo II & $\begin{array}{l}\text { 17th-16th centuries BC } \\
\text { (18th-15th centuries BC) }\end{array}$ \\
\hline & Pervomayskoye I & 16th-15th centuries BC \\
\hline & Ust-Bir I & 18th-16th centuries BC \\
\hline & Yarki II & 17th-16th centuries BC \\
\hline Karasuk culture & Karasuk I & 14th-11th centuries BC \\
\hline \multirow[t]{4}{*}{ Karasuk phase } & Okunev Ulus & 14th-10th centuries BC \\
\hline & Pervomayskoye I & 15th-14th centuries BC \\
\hline & Podgornoye Ozero I & 14th-10th centuries BC \\
\hline & Yarki I & 13th-11th centuries BC \\
\hline Transitional & Minusinsk Karyer & 14th-13th centuries BC \\
\hline \multirow[t]{2}{*}{ Kamenniy Log phase } & Kamenniy Ostrov & $\begin{array}{l}\text { 11th-10th centuries BC } \\
\text { (11th-9th centuries BC) }\end{array}$ \\
\hline & Solonechniy Log & 11th-9th centuries BC \\
\hline Tagar culture & Grishkin Log I & 9th-6th centuries BC \\
\hline Podgornovo phase & Yarki II & 9th-6th centuries BC \\
\hline \multirow[t]{3}{*}{ Podgornovo-Saragash phases } & Podgornoye Ozero & 9 th -4 th centuries $B C$ \\
\hline & Nurilkov Ulus & 8th-3rd centuries BC \\
\hline & Saragash Ozero & 8th-5th centuries BC \\
\hline \multirow[t]{2}{*}{ Saragash phase } & Lepeshkina & 4th century BC \\
\hline & Okunev Ulus & 8th-3rd centuries BC \\
\hline Tes phase & Chernoye Ozero I & 2 nd century BC -2 nd century AD \\
\hline Phase not defined & Melnichniy-Barsuchinniy Logs & 8th-4th centuries BC \\
\hline
\end{tabular}

ple of human bone has been dated. The explanation for why the wood/charcoal dates from Malinoviy Log are consistently some 6 centuries earlier is unclear at present. However, if we assume that the older dates made on wood or charcoal samples are subject to the old-wood effect and do not definitely reflect the presence of Afanasievo people in the area in the 4th millennium cal BC, we can suggest that the migration of people from the Volga-Ural region could have taken place in the Yamnaya period (late 3rd millennium BC), but not necessarily in the earlier Repin period (middle of the 3rd millennium BC). Though, again, more human bone samples need to be tested from the sites that have provided the oldest dates for the culture before certain conclusions can be made.

4. The preliminary date of the sample from the settlement of Bateni (UBA-8771; 2461-2206 cal BC) provides a much more recent date than was expected. Previously, the skeleton was thought to be the only individual of Neolithic date to have been discovered in the Minusinsk Basin (Gryaznov 1953; Vadetskaya 1986:11). However, a ${ }^{14} \mathrm{C}$ date obtained from the individual during the current study is more in keeping with the Okunevo culture. It is also worth noting that archaeologists have previously commented upon the similarity of the grave goods associated with this individual to those found in Okunevo burials (Vadetskaya 1988:69). As such, it seems probable that the burial belongs to the beginning of the Okunevo culture, although further archaeological and ${ }^{14} \mathrm{C}$ investigation is required to verify this finding.

5. The date ranges obtained for the "Classical" (14th-10th centuries BC) and Kamenniy Log (11th-9th centuries BC) phases of the Karasuk culture are generally in agreement with the 
ranges derived from previous research (14th-10th and 14th/13th-9th centuries BC, respectively). The new dates overlap each other in the 11th-10th centuries BC, which can either be the result of a small number of samples analyzed and large 2- $\sigma$ ranges of dates or indicate the coexistence of the 2 subcultures in the 11th-10th centuries BC. However, the dates we have obtained for the 2 phases of the Karasuk culture are not as contradictory as those from Sukhanikha (Görsdorf et al. 2001) and do not suggest an earlier timing of the Kamenniy Log phase of the culture (see above).

6. Overall, the new dates support the trend for the older dating of the South Siberian cultures, observed previously (e.g. Görsdorf et al. 2001:1117; Alekseev et al. 2005:223). However, the discrepancy between the traditional concept and modern ${ }^{14} \mathrm{C}$ chronology appears to diminish from the Early Bronze Age to the Early Iron Age cultures. For the Afanasievo culture, the difference is 10 to 5 centuries, but for the Tagar culture it comprises only around 2 centuries or even disappears if we take into account recent archaeological perspectives, placing the beginning of the Tagar culture at the end of the 10th century BC (e.g. Bokovenko 2006; Table 1). We need to emphasize here that, archaeologically, the timing of the Afanasievo-Andronovo cultures is based on their similarities with related Siberian cultures, themselves poorly dated, while more precise connections based on similarities with Chinese cultures are established for the Karasuk and Tagar cultures. In the meantime, the difference between archaeological and ${ }^{14} \mathrm{C}$ dating is the highest for the Afanasievo-Andronovo cultures, while it considerably decreases for the Karasuk and Tagar cultures. In other words, the difference decreases and disappears in later periods, when better cross-links to other, more securely dated cultures can be made.

7. Recent research has proposed a freshwater reservoir effect as one of the possible reasons for ${ }^{14} \mathrm{C}$ dates on human bone being older than expected. Old carbon can be introduced through the geology of the catchment area, entering the aquatic foodchain, and can affect the collagen of human populations consuming foods from such rivers and lakes. The effect, where it occurs at all, is highly variable, and ${ }^{14} \mathrm{C}$ dates of freshwater organisms can be several hundred or even thousand years older than their calendar age (Lanting and van der Plicht 1995/1996, 1998; Heinemeier et al. 1997; Heinemeier and Rud 1998; Cook et al. 2001, 2002; Khasanov and Savinetskiy 2002). Recently, research has been carried out on populations of the Khvalynsk (6th-5th millennia BC) and Catacomb (Katakomb; 5th-3rd millennia BC) cultures of the northwest Caspian Sea region, revealing a strong link between the diet of these steppe populations, consuming a significant amount of fish, and their ${ }^{14} \mathrm{C}$ age, which turned out to be $100-500 \mathrm{yr}$ earlier than terrestrial materials from the same contexts (Shishlina et al. 2006, 2007; van der Plicht et al. 2007). As fish are often at a higher trophic level than terrestrial foods, there has been an attempt to introduce a linear correlation between the $\delta^{15} \mathrm{~N}$ values and ${ }^{14} \mathrm{C}$ dates of individuals using freshwater resources in their diet (Cook et al. 2002), and to apply such preliminary corrections to the ${ }^{14} \mathrm{C}$ dates of Mesolithic-Bronze Age steppe populations of the Samara region of southwest European Russia (Anthony 2007). Depending on their $\delta^{15} \mathrm{~N}$ values, the reservoir correction for the Samara populations was proposed to vary between $-192 \pm 26$ and $-408 \pm 52 \mathrm{yr}$ (Anthony 2007:469).

Most of the archaeological sites of the Minusinsk Basin are located near freshwater resources; therefore, foods of freshwater origin, including fish, were available for the area's populations. Archaeological (Vadetskaya 1986; Savinov 1995; I Grachev, personal communication) and stable $\mathrm{C}$ and $\mathrm{N}$ isotope analysis data (Svyatko, unpublished data) also suggest freshwater fish were used to some degree by peoples of the Afanasievo through Tagar cultures. However, there appears to be no significant relationship between the $\delta^{15} \mathrm{~N}$ values and calibrated ages of analyzed individuals within each separate culture (Figure 8). If there was a marked reservoir effect, those individuals with higher $\delta^{15} \mathrm{~N}$ values would on average be expected to exhibit earlier ${ }^{14} \mathrm{C}$ 
ages than those with lower values. Therefore, there is no convincing evidence to suggest that the reservoir effect has affected the ${ }^{14} \mathrm{C}$ dating results presented here to any great extent.

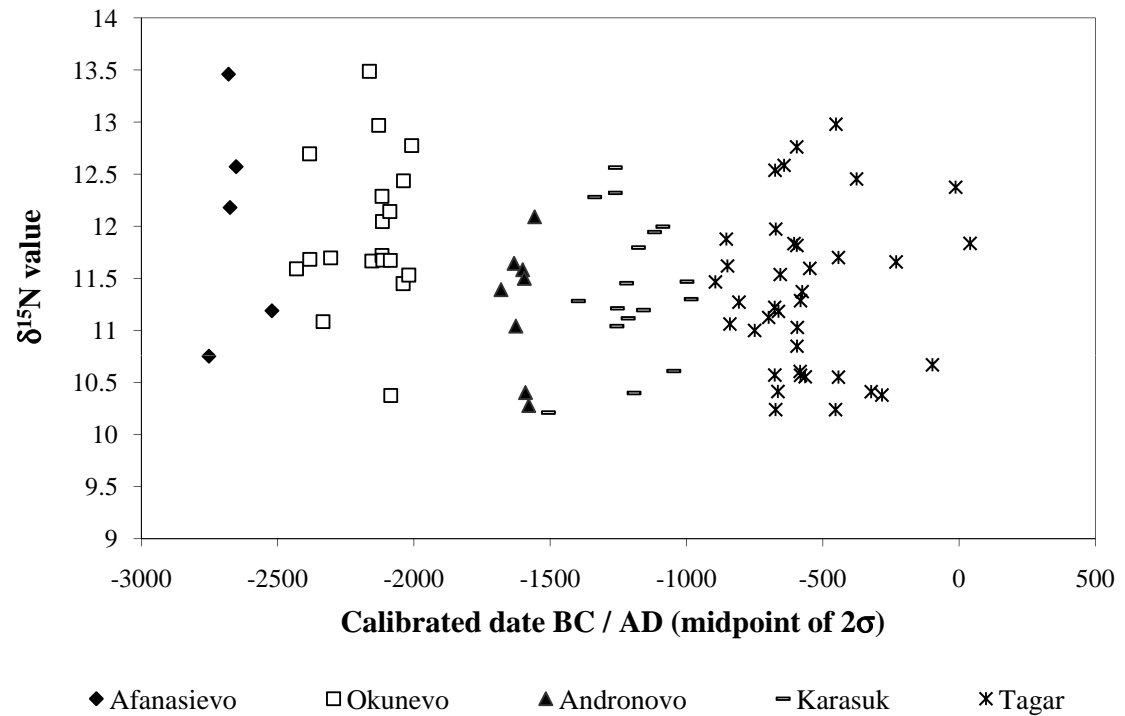

Figure 8 Relationship between the $\delta^{15} \mathrm{~N}$ values and calibrated age of individuals analyzed

8. On the basis of the ${ }^{14} \mathrm{C}$ dating, a chronological gap appears to have occurred in the southern Minusinsk Basin in the 19th to the mid-18th centuries BC, between the Okunevo and Andronovo cultures. None of the 28 humans dated to the Okunevo and Andronovo cultures fall within this period (Figure 9). The calibration curve does not show any major fluctuations between 1900 and $1750 \mathrm{cal} \mathrm{BC}$, so possible reasons for the gap include the use of a non-representative sample in the current study; a change in burial practice, which lowered the visibility of individuals; or a phase of depopulation in the Minusinsk Basin for a period of 150 yr.

The Okunevo samples included in the present study were derived from 4 sites located in the minor Minusinsk Basin (Okunev Ulus, Uibat III, Uibat V, and Verhniy Askiz I). From past research, most of the calibrated dates taken from bone samples from the minor Minusinsk Basin also fall outside of the period. The only exceptions are 2 specimens derived from the Karasuk site of Anchil-Chon (Le5285 and -5507), providing calibrated date ranges of 2033-1526 and 1874-1319 cal BC, respectively. Unfortunately, further contextual information is not available for these individuals, which might help explain their dating results. However, it is clear that before further conclusions can be drawn concerning this possible hiatus in activity, it is necessary to obtain ${ }^{14} \mathrm{C}$ dates from many more samples, particularly of human bone.

In a wider context, there is a strong opinion among archaeologists that in the northern part of the Minusinsk Basin, the culture came to an end because the population was forced out of the territory by the people of the succeeding Andronovo culture, while in the southern part the Okunevo culture could have lasted for a longer period of time, possibly until the Karasuk culture (no Andronovo sites have yet to be identified in the minor Minusinsk Basin). Therefore, there may have been a degree of coexistence between the tribes of the Okunevo and Andronovo cultures in different parts of the Minusinsk Basin (Semenov 1984:253, 1997:157-160; Vadetskaya 1986:36, 46; Molodin 1992:29; Lazaretov 2001:104, 2007:41; Savinov 2002:24,32). No major climatic changes are reported for the 


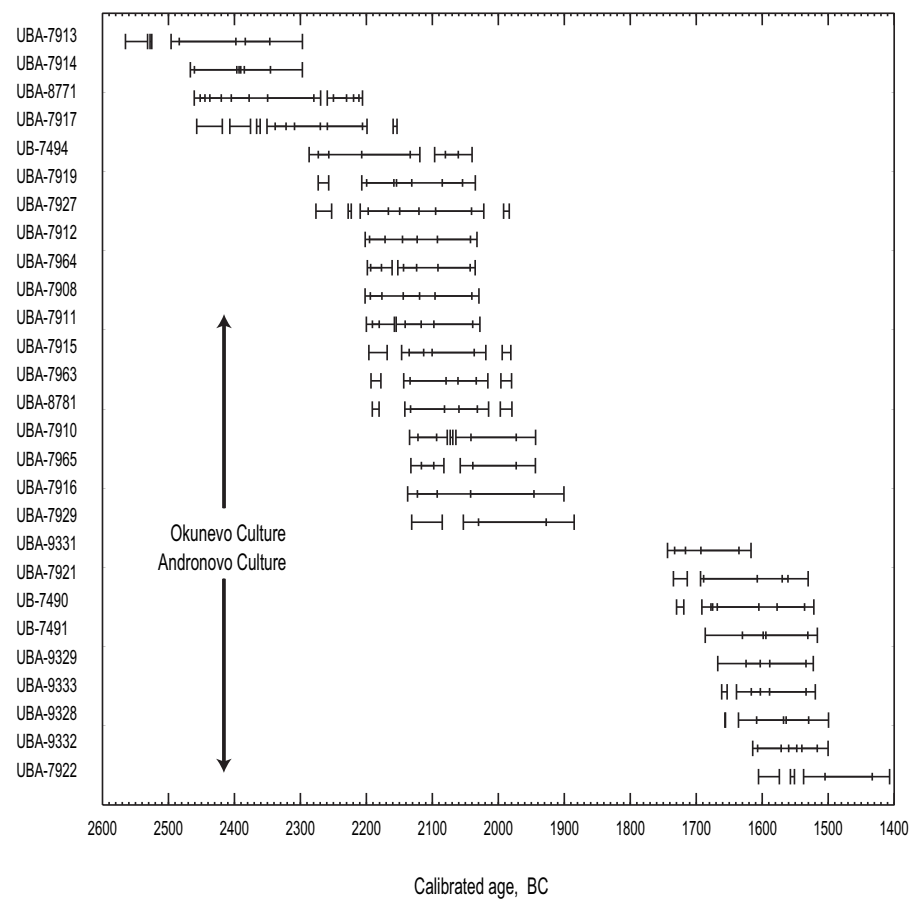

Figure 9 Calibrated age ranges (1 and $2 \sigma$ ) showing the chronological gap between the Okunevo and Andronovo cultures.

period (Dirksen and van Geel 2004; Koulkova 2004; Dirksen et al. 2007). However, it has been noted that a cold and wet climate prevailed in the area from $\sim 5$ cal kyr BP, which would have provided severe living conditions for the Okunevo population. This apparently changed to drier climate at $~ 3.6$ cal kyr BP. It has been suggested that the degree of aridity and continentality may have increased progressively from the northern part of the basin to the south. This may have restricted successful habitation of the entire area by the people of the succeeding Andronovo culture (Dirksen et al. 2007).

Importantly, in the Tuva region to the south of the Minusinsk Basin, a major chronological gap is observed between the turn of the 3rd/2nd millennia BC and 9th century BC (van Geel et al. 2004: 155). No evidence exists for the presence of any cultures in the area in the first half of the $2 \mathrm{nd} \mathrm{mil-}$ lennium BC; small-scale occupation of the territory began in the second half of the 2nd millennium $\mathrm{BC}$, while a major occupation of the territory occurred in the 1st millennium $\mathrm{BC}$. The poor environmental conditions and dry climate that predominated in the region until the Middle Bronze Age have been suggested as a possible explanation for the gap. It has also been proposed that as Tuva, to the south of the Basin, became too dry, the Minusinsk Basin may have become more attractive for settlement (Zaitseva et al. 2004).

To conclude, it should be noted that a ${ }^{14} \mathrm{C}$ chronology for the prehistoric cultures of the Minusinsk Basin is still under development. Nevertheless, the new ${ }^{14} \mathrm{C}$ data reported in this paper constitute a large collection of high-quality ${ }^{14} \mathrm{C}$ dates derived from single-entity samples of human bone for the Eneolithic to Early Iron Age periods for the region. The ${ }^{14} \mathrm{C}$ dates derived from previous research and during the course of the present project have confirmed the general chronological sequence of the Afanasievo to Tagar cultures, but much work remains to refine the timing of the transitions between cultures and the timing of the particular phases of the Karasuk and Tagar cultures. 


\section{ACKNOWLEDGMENTS}

This research is supported by the ${ }^{14} \mathrm{CHRONO}$ Centre for Climate, the Environment and Chronology, funded by the Atlantic Philanthropies and the Department for Employment and Learning, Northern Ireland. The authors would like to acknowledge Prof Yuri K Chistov, Dr Valeri I Khartanovich, and Igor A Grachev (Peter the Great Museum of Anthropology and Ethnography, RAS, St Petersburg); and Dr Olga V Kovaleva and Dr Nikolai V Leontyev (I M Martyanov Minusinsk Regional Museum, Minusinsk) for permitting samples to be taken from their anthropological collections. We are also very grateful to Dr Ganna I Zaitseva of the Laboratory of Archaeological Technology, Institute for the History of Material Culture RAS, St Petersburg, for providing background information on particular ${ }^{14} \mathrm{C}$ dates. We would also like to thank staff in the CHRONO laboratory, particularly Michelle Thompson, James McDonald, and Ron Reimer, for their generous help with the preparation of the samples and numerous helpful discussions.

\section{REFERENCES}

Alekseev AYu, Bokovenko NA, Boltrik Yu, Chugunov KA, Cook G, Dergachev VA, Kovalyukh N, Possnert G, van der Plicht J, Scott EM, Sementsov A, Skripkin V, Vasiliev S, Zaitseva G. 2001. A chronology of the Scythian antiquities of Eurasia based on new archaeological and ${ }^{14} \mathrm{C}$ data. Radiocarbon 43(2B):1085-107.

Alekseev AYu, Bokovenko NA, Boltrik Yu, Chugunov KA, Cook G, Dergachev VA, Kovaliukh N, Possnert G, van der Plicht J, Scott EM, Sementsov A, Skripkin V, Vasiliev S, Zaitseva G. 2002. Some problems in the study of the chronology of the ancient nomadic cultures of Eurasia (9th-3rd centuries BC). Geochronometria 21:143-50.

Alekseev AYu, Bokovenko NA, Vasiliev SS, Dergachev VA, Zaitseva GI, Kovaliukh NN, Cook G, van der Plicht J, Possnert G, Sementsov AA, Scott EM, Chugunov KV. 2005. Eurasia in Scythian Time: Radiocarbon and Archaeological Chronology. St Petersburg: THESA.

Alekseev VP. 1961. Antropologicheskie tipy Yuzhnoi Sibiri (Altae-Sayanskoe nagorye) $\mathrm{v}$ epohu neolita $\mathrm{i}$ bronzy [Anthropological types of Southern Siberia (Altai-Sayan Plateau) in the Neolithic and Bronze Age]. In: Shunkov VI, editor. Voprosy Istorii Sibiri i Dalnego Vostoka (Trudy Konferencii po Istorii Sibiri i Dalnego Vostoka). Novosibirsk: Sibirskoye Otdeleniye, Akademiya Nauk SSSR. p 377-85. In Russian.

Alekseev VP, Gokhman II. 1984. Antropologiya Aziatskoi Chasti SSSR [Anthropology of the Asian Part of the USSR]. Moscow: Nauka. In Russian.

Anthony DW. 2007. The Horse, the Wheel, and Language: How Bronze-Age Riders from the Eurasian Steppes Shaped the Modern World. Princeton: Princeton University Press. 553 p.

Beer N. 2004. An investigation into the diet of two Scythian period populations from Southern Siberia, utilizing stable isotope and dental palaeopathological analyses [MSc thesis]. Belfast: Queen's University Belfast.

Bobrov VV. 2003. Dva drevhih istoriko-kulturnyh mira Zapadnoy Sibiri: problema vzaimodeystviya [The two ancient cultural-historical worlds of Western Siberia: the problem of interrelation]. In: Bobrov VV, Rusakova ID, editors. Arkheologiya Yuzhnoi Sibiri. Novosibirsk: Siberian Branch of Russian Academy of Sciences Press. In Russian.

Bokovenko N. 2006. The emergence of the Tagar culture. Antiquity 80(310):860-79.

Bokovenko NA, Legrand S. 2000. Das Karasukzeitliche Gräberfeld Anil on in Chakassien. Eurasia Antiqua 6: 209-48. In German.

Bronk Ramsey C. 1995. Radiocarbon calibration and analysis of stratigraphy: the OxCal program. Radiocarbon 37(2):425-30.

Bronk Ramsey C. 2001. Development of the radiocarbon calibration program. Radiocarbon 43(2A):355-63.

Bronk Ramsey C, Higham TFG, Bowles A, Hedges R. 2004. Improvements to the pretreatment of bone at Oxford. Radiocarbon 46(1):155-63.

Brown TA, Nelson DE, Vogel JS, Southon JR. 1988. Improved collagen extraction by modified Longin method. Radiocarbon 30(2):171-7.

Butomo SV. 1965. Radiocarbon dating in the Soviet Union. Radiocarbon 7:223-8.

Chlenova NL. 1972. Hronologiya Pamyatnikov Karasukskiy Epohi [The Chronology of Monuments of the Karasuk Époque]. Moscow: Nauka. In Russian.

Cook GT, Bonsall C, Hedges REM, McSweeney K, Boroneant V, Pettitt PB. 2001. A freshwater diet-derived ${ }^{14} \mathrm{C}$ reservoir effect at the Stone Age sites in the Iron Gates Gorge. Radiocarbon 43(2A):453-60.

Cook GT, Bonsall C, Hedges REM, McSweeney K, Boroneant V, Bartosiewicz L, Pettitt PB. 2002. Problems of dating human bones from the Iron Gates. Antiquity 76(291):77-85.

DeNiro MJ. 1985. Postmortem preservation and alteration of in vivo bone collagen isotope ratios in relation to palaeodietary reconstruction. Nature 317(6040): 806-9.

Dirksen VG, van Geel B. 2004. Mid to late Holocene climate change and its influence on cultural development 
in South Central Siberia. In: Scott EM, Alekseev AY, Zaitseva GI, editors. Impact of the Environment on Human Migration in Eurasia. Dordrecht: Kluwer Academic Publishers. p 291-307.

Dirksen VG, van Geel B, Koulkova MA, Zaitseva GI, Sementsov AA, Scott EM, Cook GT, van der Plicht J, Lebedeva LM, Bourova ND, Bokovenko NA. 2007. Chronology of Holocene climate and vegetation changes and their connection to cultural dynamics in Southern Siberia. Radiocarbon 49(2):1103-21.

Ermolova NM, Markov Yu N. 1983. Datirovanie arheologicheskih obrazcov iz mogilnikov epohi bronzy Yuzhnoi Sibiri [Dating of archaeological samples from cemeteries of the Iron Age from Southern Siberia]. In: Masson VM, editor. Drevnie Kultury Evraziiskih Stepei. Leningrad: Nauka Press. p 95-7. In Russian.

Görsdorf J. 2002. Datierungsergebnisse des Berlinen ${ }^{14} \mathrm{C}$-Labors 2001. Eurasia Antiqua 8:553-60. In German.

Görsdorf J. 2004. Datierungsergebnisse des Berlinen ${ }^{14}$ C-Labors 2003. Eurasia Antiqua 10:401-9. In German.

Görsdorf J, Parzinger H, Nagler A, Leontyev N. 1998a. Neue ${ }^{14} \mathrm{C}$-Datierungen für die Sibirische Steppe und ihre Konsequenzen für die regionale Bronzezeitchronologie. Eurasia Antiqua 4:73-80. In German.

Görsdorf J, Parzinger H, Nagler A, Leont'ev N. 1998b. New radiocarbon dates from the Siberian Steppe Zone and consequences for the regional Bronze Age chronology. Actes du colloque "C14 Archéologie" 1998. Revue d'Archéométrie (Supplement 1999):305-9.

Görsdorf J, Parzinger H, Nagler A. 2001. New radiocarbon dates of the North Asian steppe zone and its consequences for the chronology. Radiocarbon 43(2B): $1115-20$.

Görsdorf J, Parzinger H, Nagler A. 2004. ${ }^{14} \mathrm{C}$ dating of the Siberian Steppe Zone from Bronze Age to Scythian time. In: Scott EM, Alekseev AY, Zaitseva GI, editors. Impact of the Environment on Human Migration in Eurasia. Dordrecht: Kluwer Academic Publishers. p 83-9.

Grachev IA. 2006. Fortificatsionniye osobennosti krepostnyh sooruzheniy epokhi pozdney bronzy Khakassko-Minusinskogo regiona [Fortification features of fortress constructions of the Late Bronze Age in the Khakas-Minusinsk region]. In: Chistov YuK, Mikhailova EA, editors. Radlovskiye Chteniya 2006: Tezisy Dokladov. St Petersburg: MAE RAN. p 253-6. In Russian.

Gryaznov MP. 1953. Neoliticheskoye pogrebeniye v s Bateni na Enisee [The Neolithic burial in the settlement of Bateni in the Yenisey region]. Materialy i Issledovaniya po Arkheologii SSSR 39:332-5. In Russian.

Gryaznov MP. 1969. The Ancient Civilization of Southern Siberia: An Archaeological Adventure. New York: Cowles Book Company. 252 p.
Gryaznov MP. 1999. Afanasievskaya Kultura na Yenisee [The Afanasievo Culture in the Yenisey Region]. St Petersburg: Dmitriy Bulanin. In Russian.

Gryaznov MP, Vadetskaya EB. 1968. Afanasievskaya kultura [The Afanasievo culture]. In: Okladnikov AP, Shunkov, editors. The History of Siberia from Ancient Times to Present Day. Volume 1. Leningrad: Nauka. p 159-65. In Russian.

Hall ME. 1999. The absolute chronology of the Tagar culture. Eurasian Studies Yearbook 71:5-18.

Heinemeier J, Rud N. 1998. Danske arkæologiske AMS ${ }^{14} \mathrm{C}$ dateringer, Århus 1997. Arkaologiske Udgravningeri Danmark 1997:282-92. In Danish.

Heinemeier J, Boaretto E, Christiansen C, Kristensen PK, Nielsen HL, Rud N, Sveinbjörnsdóttir AE. 1997. ${ }^{14} \mathrm{C}$ and stable isotopes in contemporary seawater in a transect from the North Sea to the Baltic Sea. Book of Abstracts, 16th International Radiocarbon Conference, Groningen, 16-21 June 1997. p 73.

Khasanov BF, Savinetskiy AB. 2002. Parallelnyye datirovki morskih i nazemnyh organizmov iz severnoy chasto Beringovogo moray [Parallel dating of marine and terrestrial organisms from the north Bering Sea]. In: Kozlovskaya M, editor. OPUS: Interdisciplinary Investigation in Archaeology. Volumes 1-2. Moscow: Institute of Archaeology, Russian Academy of Sciences. In Russian.

Khavrin SV. 1992. Pamyatniki andronovskoi kultury na territorii Severnogo Kitaya [The sites of the Andronovo culture in the territory of the northern China]. In: Masson VM, editor. Severnaya Evraziya ot Drevnosti do Srednevekovya. Arkheologicheskiye Izyskaniya 2. St Petersburg: State Hermitage Press. p 43-5. In Russian.

Khlobystina MD. 1973. Proishizhdeniye i razvitiye kultury ranney bronzy Yuzhnoy Sibiri [The emergence and development of the Early Bronze culture of Southern Siberia]. Sovetskaya Arkheologiya 1:24-38. In Russian.

Kiselev SV. 1951. Drevnyaya Istoriya Yushnoy Sibiri [The Ancient History of Southern Siberia]. Moscow: Akademiya Nauk SSSR Press. In Russian.

Komarova MN. 1947. Pogrebeniya Okuneva ulusa [Burials of the Okunev Ulus]. Sovetskaya Arkheologiya IX:47-59. In Russian.

Koulkova MA. 2004. Applications of geochemistry to paleoenvironmental reconstruction in Southern Siberia. In: Scott EM, Alekseev AY, Zaitseva GI, editors. Impact of the Environment on Human Migration in Eurasia. Dordrecht: Kluwer Academic Publishers. p 255-74.

Kuzmin NYu. 2008. Prospects for correlating radiocarbon and archaeological chronologies of the Scythian and Hunno-Sarmatian Age burials in the Sayan-Altai region. Archaeology, Ethnology \& Anthropology of Eurasia 35(3):77-87.

Kuzmina E. 2007. The Origin of the Indo-Iranians. Lei- 
den: Brill Academic Publishers. 766 p.

Kyzlasov LR. 1986. Drevneyshaya Hakasiya [Ancient Khakasia]. Moscow: Moscow University Press. In Russian.

Kyzlasov LR. 1992. Ocherki po Istorii Sibiri i Centralnoy Azii [Studies on the History of Siberia and Central Asia]. Krasnoyarsk: Krasnoyarsk University Press. In Russian.

Lanting JN, van der Plicht J. 1995/1996. Wat hebben Floris V, skelet Swifterbant S2 en visotters gemeen? Palaeohistoria 37-38:491-520. In Dutch.

Lanting JN, van der Plicht J. 1998. Reservoir effect and apparent ${ }^{14} \mathrm{C}$ ages. The Journal of Irish Archaeology 9 : $151-65$.

Lazaretov IP. 1995. K voprosu o yamno-katakombnyh svyazyah okunevskoy cultury [On the question of the Yamnaya-Catacombnaya links of the Okunev culture]. In: Savinov DG, editor. Problemy Izucheniya Okunevskoy Kulturi. St Petersburg: State Hermitage Press. p 14-6. In Russian.

Lazaretov IP. 2001. Lokalizatsiya i problemy vzaimodeystviya kultur Yuzhnoy Sibiri [The localization and problems of interrelation of the cultures of Southern Siberia]. In: Froyanov IYa, Astakhov SN, editors. Evraziya Skvoz. Veka. St Petersburg: Filologicheskiy Fakultet, Sankt-Peterburgskiy Gosudartsvenniy Universitet Press. p 103-7. In Russian.

Lazaretov IP. 2006. Zakluchitelniy Etap Epohi Bronzy na Srednem Enisee [The Final Stage of the Bronze Age on the Middle Yenisey]. Candidate of Sciences dissertation. St Petersburg: Institute for the History of Material Culture. In Russian.

Lazaretov IP. 2007. Okunevskiye mogilniki v doline reki Uibat [Okunevo graves in the valley of the Uibat River]. In: Savinov DG, Podolskiy ML, editors. Okunevskiy Sbornik: Kultura, Iskusstvo, Antropologiya. St Petersburg: State Hermitage Press. p 19-64. In Russian.

Leontyev N, Parzinger H, Nagler A. 1996. Die russischdeutschen Ausgrabungen beim Berg Suchanicha am mittleren Enisej. Eurasia Antiqua 2:175-204. In German.

Maksimenkov GA. 1965. Okunevskaya Kultura v Yuzhnoy Sibiri [The Okunevo culture in Southern Siberia]. Materialy i Issledovaniya po Arkheologii SSSR 130: 168-74. In Russian.

Maksimenkov GA. 1968a. Andronovskoye vramya v Yuzhnoy Sibiri [Andronovo times in Southern Siberia]. In: Okladnikov AP, Shunkov VI, editors. The History of Siberia from Ancient Times to Present Day. Volume 1. Leningrad: Nauka. p 172-80. In Russian.

Maksimenkov GA. 1968b. Pkunevskaya kultura i ee sosedi na Obi [The Okunevo culture and its neighbors in the Ob region]. In: Okladnikov AP, Shunkov VI, editors. The History of Siberia from Ancient Times to Present Day. Volume 1. Leningrad: Nauka. p 165-72. In Russian.
Maksimenkov GA. 1975a. Okunevskaya Kultura [The Okunevo culture]. PhD dissertation. Novosibirsk: Joint Academic Council for Philological-Historical and Philosophical Sciences of the Siberian Branch of the Russian Academy of Sciences. In Russian.

Maksimenkov GA. 1975b. Sovremennoe sostoyanie voprosa o periodizacii epohi bronzy Minusinskoy kotloviny [The present day status of the question of Bronze Age periodization for the Minusinsk Basin]. In: Mandelshtam AM, editor. Pervobytnaya Arkheologiya Sibiri. Leningrad: Nauka. p 48-58. In Russian.

Mallory JP, McCormac FG, Reimer PJ, Marsadolov LS. 2002. The date of Pazyryk. In: Boyle K, Renfrew C, Levine M, editors. Ancient Interactions: East and West in Eurasia. Cambridge: McDonald Institute for Archaeological Research. p 199-211.

Martynov AI. 1964. Andronovskaya cultura [The Andronovo culture]. In: Okladnikov AP, Larichev VE, editors. Drevnyaya Sibir. Volume I (model). UlanUde. p 249-61. In Russian.

Molodin VI. 1992. Bronzovyy vek Yuzhnoy Sibiri sovremennoye sostoyaniye problemy [The Bronze Age of Southern Siberia - the modern state of the problem]. In: Pustogachev YaA, Surazakov AS, editors. Problemy Izucheniya Istorii i Kultury Altaya I Sopredelnyh Territoriy. Gorno-Altaysk. In Russian.

Panyushkina IP, Mills BJ, Usmanova ER, Cheng L. 2008. Calendar age of Lisakovsky timbers attributed to Andronovo community of Bronze Age in Eurasia. Radiocarbon 50(3):459-69.

Polyakov AV. 2006. Periodizatsiya "Klassicheskogo" Etapa Karasukskoy Kultury (po Materialam Pogrebalnih Pamyatnikov) [Periodization of the "Classical" phase of the Karasuk culture (based on data derived from burial sites)]. Candidate of Sciences dissertation synopsis. St Petersburg: Institute for the History of Material Culture. In Russian.

Reimer PJ, Baillie MGL, Bard E, Bayliss A, Beck JW, Bertrand CJH, Blackwell PG, Buck CE, Burr GS, Cutler KB, Damon PE, Edwards RL, Fairbanks RG, Friedrich M, Guilderson TP, Hogg AG, Hughen KA, Kromer B, McCormac G, Manning S, Bronk Ramsey C, Reimer RW, Remmele S, Southon JR, Stuiver M, Talamo S, Taylor FW, van der Plicht J, Weyhenmeyer CE. 2004. IntCal04 terrestrial radiocarbon age calibration, 0-26 cal kyr BP. Radiocarbon 46(3):102958.

Savinov DG. 1995. Okunevskaya problema I neskolko podhodov k ee resheniyu [The Okunevo problem and some methods for its solution]. In: Savinov DG, editor. Problemy Izucheniya Okunevskoy Kulturi. St Petersburg: State Hermitage Press. p 2-7. In Russian.

Savinov DG. 2002. Rannie Kochevniki Verhnego Eniseya: Arheologicheskie Kultury i Kulturogenez. [The Early Nomads of the Upper Yenisey: Archaeological Cultures and Culturogenesis]. St Petersburg: Sankt- 
Peterburgskiy Gosudartsvenniy Universitet Press. In Russian.

Savinov DG. 2005. K probleme vydeleniya pozdnego etapa okunevskoy kultury [On the problem of separation of the late stage of the Okunevo culture]. In: Tishkin AA, editor. Teotiya i practika Arkheologicheskih issledovaniy. Volume 1. Barnaul: Altai University Press. p 28-34. In Russian.

Scott EM, Alekseev AY, Zaitseva GI, editors. 2004. Impact of the Environment on Human Migration in Eurasia. Dordrecht: Kluwer Academic Publishers. 334 p.

Semenov VA. 1984. O dvuh etapah okunevskoi kultury v Tuve [On the two stages of the Okunev culture in Tuva]. In: Aranchyn YuL, editor. Problemy Istorii Tuvy. Kyzyl: Tuva Research Institute for Linguistics and History Press. p 252-62. In Russian.

Semenov VA. 1987. Drevneyamnaya kultura - Afanasievskaya kultura i problema prototoharskoi emigracii na vostok [The ancient Yamnaya culture - the Afanasievo culture and a problem of Proto-Tokhar migration to the East]. In: Pletneva LM, editor. Smeny Kultur i Migracii v Zapadnoi Sibiri. Tomsk: Tomsk University Press. p 17-20. In Russian.

Semenov VA. 1997. Okunevskiye pamyatniki Tuvy i Minusinskoy kotloviny (sravnitelnaya harakteristika i hronologiya) [Okunevo sites of Tuva and the Minusinsk Basin (relative description and chronology)]. In: Savinov DG, Podolskiy ML, editors. Okunevskiy Sbornik: Kultura, Iskusstvo, Antropologiya. St Petersburg: State Hermitage Press. p 152-60. In Russian.

Sementsov AA, Romanova YeN, Dolukhanov PM. 1969. Radiouglerodnyye daty laboratorii LOIA [Radiocarbon dates of the laboratory of LOIA]. Sovetskaya Arkheologiya 1:251-61. In Russian.

Sementsov AA, Zaitseva GI, Görsdorf J, Nagler A, Parzinger $\mathrm{H}$, Bokovenko NA, Chugunov KV, Lebedeva LM. 1998. Chronology of the burial finds from Scythian monuments in Southern Siberia and Central Asia. Radiocarbon 40(2):713-20.

Semyontsov AA, Dolukhanov PM, Romanova YeN, Timofeyev VI. 1972. Radiocarbon dates of the Institute of Archaeology III. Radiocarbon 14(2):336-67.

Shishlina NI, van der Plicht J, Zazovskaya EP, Sevastyanov VS, Chechagova OA. 2006. K voprosu o radiouglerodnom vozraste eneoliticheskih kultur evraziyskoy stepi [On the question of the radiocarbon age of the Eneolithic cultures of the Eurasian Steppe]. Voprosy Arkheologii Povolzhya 4:135-40. In Russian.

Shishlina NI, van der Plicht J, Hedges REM, Zazovskaya EP, Sevastyanov VS, Chichagova OA. 2007. The Catacomb cultures of the north-west Caspian Steppe: ${ }^{14} \mathrm{C}$ chronology, reservoir effect, and paleodiet. Radiocarbon 49(2):713-26.

Slota Jr PJ, Jull AJT, Linick TW, Toolin LJ. 1987. Preparation of small samples for ${ }^{14} \mathrm{C}$ accelerator targets by catalytic reduction of CO. Radiocarbon 44(1):16780.
Sokolova LA. 2002. Harakteristika i tipologiya okunevskogo keramicheskogo kompleksa [Description and typology of the Okunevo ceramics complex]. In: Piotrovskiy YuYu, editor. Stepi Evrazii v Drevnosti $i$ Srednevekovye. St Petersburg: State Hermitage Press. p 230-6. In Russian.

Sokolova LA. 2006. Tipologiya pogrebalnyh pamyatnikov Okunevskoy kultury [The typology of burials of the Okunevo culture]. Savinov DG, Podolskiy ML, editors. Okunevskiy Sbornik: Kultura, Iskusstvo, Antropologiya. St Petersburg: State Hermitage Press. p 251-9. In Russian.

Stuiver M, Polach HA. 1977. Discussion: reporting of ${ }^{14} \mathrm{C}$ data. Radiocarbon 19(3):355-63.

Stuiver M, Reimer PJ, Reimer RW. 2005. CALIB 5.0. [WWW program and documentation]. URL: http://radiocarbon.pa.qub.ac.uk/calib/calib.html.

Teploukhov CA. 1929. Opyt klassifikatsii drevnih metallicheskih kultur Minusinskogo kraya [The experience of classification of the Metal Age cultures of the Minusinsk region]. Materialy po Etnografii IV(2):41-62. In Russian.

Vadetskaya EB. 1981. Afanasievskiy mogilnik Krasnyy Yar [The Afanasievo cemetery of Krasniy Yar]. In: Troitskaya TN, editor. Problemy Zapadnosibirskoy Arkheologii: Epoha Kamnya i Bronzy. Novosibirsk: Nauka. p 13-21. In Russian.

Vadetskaya EB. 1986. Arkheologicheskiye Pamyatniki v Stepyakh Srednego Yeniseya [Archaeological Sites in the Steppes of the Middle Yenisey]. Leningrad: Nauka. In Russian.

Vadetskaya EB. 1988. Sovremenniye predstavleniya o sostoyanii istochnikov po neolitu Minusinskoi kotloviny [The modern conception of the state of sources on the Neolithic of the Minusinsk Basin]. Kratkiye Soobsheniya Institute Arkheologii 199:68-73. In Russian.

van der Plicht J, Shishlina NI, Hedges REM, Zazovskaya EP, Sevastyanov VS, Chichagova OA. 2007. Rezervuarnyy effect i rezultaty datirovaniya katakombnyh kultur severo-zapadnogo Prikaspiya [The reservoir effect and dating results for the Catacomb cultures of the northwest Caspian Sea region]. Rossiyskaya Arkheologiya 2:39-47. In Russian.

van Geel B, Bokovenko NA, Burova ND, Chugunov KV, Dergachev VA, Dirksen VG, Kulkova M, Nagler A, Parzinger H, van der Plicht J, Vasiliev SS, Zaitseva GI. 2004. The Sun, climate change and the expansion of the Scythian culture after 850 BC. In: Scott EM, Alekseev AY, Zaitseva GI, editors. Impact of the Environment on Human Migration in Eurasia. Dordrecht: Kluwer Academic Publishers. p 151-8.

Vinogradov AV. 1982. Neolit i Rannii Bronzovyi Vek Minusinskoi Kotloviny [The Neolithic and Early Bronze Age of the Minusinsk Basin]. Candidate of Sciences dissertation synopsis. Leningrad: Leningradskiy Gosudarstvenniy Universitet Press.

Vogel JS, Nelson DE, Southon JR. 1987. ${ }^{14} \mathrm{C}$ background 
levels in an accelerator mass spectrometry system. $R a$ diocarbon 29(3):323-33.

Zaitseva GI, van Geel B. 2004. The occupation history of Southern Eurasia Steppe during the Holocene: chronology, the calibration curve and methodological problems of the Scythian chronology. In: Scott EM, Alekseev AY, Zaitseva GI, editors. Impact of the Environment on Human Migration in Eurasia. Dordrecht: Kluwer Academic Publishers. p 63-82.

Zaitseva GI, van Geel B, Bokovenko NA, Chugunov KV, Dergachev VA, Dirksen VG, Koulkova MA, Nagler A,
Parzinger G, van der Plicht J, Bourova ND, Lebedeva LM. 2004. Chronology and possible links between climatic and cultural change during the first millennium $\mathrm{BC}$ in southern Siberia and Central Asia. Radiocarbon 46(1):259-76.

Zimina VM. 1964. Afanasievskaya kultura (III - nachalo II tisyacheletiya do n.e.) [The Afanasievo culture (3rd-beginning of 2nd millennium BC)]. In: Okladnikov AP, Larichev BE, editors. Drevnyaya Sibir. Volume I (model). Ulan-Ude. p 235-42.

\section{APPENDICES}

Appendix $1{ }^{14} \mathrm{C}$ dates of the Afanasievo culture: previous research $(n=24)$.

\begin{tabular}{|c|c|c|c|c|c|}
\hline Lab ID & Material & $\begin{array}{l}\delta^{13} \mathrm{C} \\
(\% o) \\
\end{array}$ & Provenance & ${ }^{14} \mathrm{C} \mathrm{BP}$ & $\begin{array}{l}\text { Age, cal BC } \\
(2 \sigma)\end{array}$ \\
\hline Le-532b & wood & - & Chernovaya VI, kurgan 4 , grave 3 & $3700 \pm 80$ & $2345-1883$ \\
\hline Le-8517 & wood & - & Itkol II, kurgan 27 , grave 1 & $4170 \pm 30$ & $2882-2635$ \\
\hline Le-930c & wood & - & Krasniy Yar I, kurgan 7 & $4080 \pm 40$ & $2862-2489$ \\
\hline Le-931 ${ }^{\mathrm{c}}$ & wood & - & Krasniy Yar I, kurgan 9 & $4170 \pm 50$ & $2890-2589$ \\
\hline Le-1067d & wood & - & Krasniy Yar I, kurgan 12 & $4240 \pm 60$ & $3011-2626$ \\
\hline Le-1068 & wood & - & Krasniy Yar I, kurgan 15 & $4160 \pm 40$ & $2882-2622$ \\
\hline Le- $1611^{\mathrm{e}}$ & wood/charcoal & - & Letnik VI, enclosure 13 & $4250 \pm 40$ & 2926-2679 \\
\hline Le-1612d & - & - & Letnik VI & $4410 \pm 50$ & 3330-2909 \\
\hline Le-2115e & wood/charcoal & - & Letnik VI, enclosure 14 & $4410 \pm 50$ & 3330-2909 \\
\hline Le-2116 & wood/charcoal & - & Letnik VI, enclosure 14 & $4380 \pm 50$ & 3319-2895 \\
\hline Le-2094e & wood/charcoal & - & Malinoviy Log, enclosure 1 , grave 1 & $4770 \pm 60$ & $3653-3375$ \\
\hline Le-2091 e & wood/charcoal & - & Malinoviy Log, enclosure 4, grave 1 & $4780 \pm 50$ & $3654-3378$ \\
\hline Le-2092e & wood/charcoal & - & Malinoviy Log, enclosure 4 , grave 1 & $4790 \pm 50$ & $3659-3379$ \\
\hline Le-2093e & wood/charcoal & - & Malinoviy Log, enclosure 4 , grave 1 & $4820 \pm 50$ & $3705-3384$ \\
\hline Le- $455^{b}$ & charcoal & - & Maliye Kopeny II, kurgan 2 & $4440 \pm 150$ & $3625-2679$ \\
\hline Le-694 & wood & - & Sargov Ulus, grave 3 & $4270 \pm 60$ & $3083-2668$ \\
\hline $\mathrm{B} \ln -4764^{\mathrm{f}}$ & wood & - & Sukhanikha, stone circle, object 6 & $4409 \pm 70$ & $3337-2903$ \\
\hline $\mathrm{B} \ln -4765^{\mathrm{f}}$ & wood & -24.86 & Sukhanikha, stone circle, object 6 & $4259 \pm 36$ & $2926-2702$ \\
\hline$B \ln -4766^{\mathrm{f}}$ & wood & -24.82 & Sukhanikha, grave 2 , object 2 & $4205 \pm 44$ & $2903-2636$ \\
\hline $\mathrm{B} \ln -4767^{\mathrm{f}}$ & wood & -25.27 & Sukhanikha, grave 1 , object 6 & $4253 \pm 36$ & $2922-2701$ \\
\hline$B \ln -4769^{f}$ & wood & -24.08 & Sukhanikha, grave 1 , object 6 & $4022 \pm 40$ & $2833-2466$ \\
\hline $\mathrm{B} \ln -4919 \mathrm{~g}$ & wood & -24.90 & Sukhanikha, grave 15 , object 6 & $3936 \pm 35$ & $2565-2299$ \\
\hline $\mathrm{B} \ln -5280^{\mathrm{g}, \mathrm{h}}$ & wood & -25.7 & Sukhanikha II, burial mound 19a, grave 1 & $4271 \pm 30$ & $2925-2779$ \\
\hline Le-1316 ${ }^{\mathrm{d}}$ & - & - & Vostochnoye & $3880 \pm 30$ & $2467-2235$ \\
\hline \multicolumn{6}{|c|}{$\begin{array}{l}\text { a Here and in other Appendix tables: dates were calibrated with CALIB 5.0.2 (Stuiver et al. 2005) using the IntCal04 calibration } \\
\text { curve (Reimer et al. 2004). }\end{array}$} \\
\hline \multicolumn{6}{|c|}{ b'Sementsov et al. 1969:258. } \\
\hline \multicolumn{6}{|c|}{ cVadetskaya 1981:62. } \\
\hline \multicolumn{6}{|c|}{ dZaitseva and van Geel 2004.} \\
\hline \multicolumn{6}{|c|}{${ }^{\mathrm{e} E r m o l o v a}$ and Markov 1983:95-6. } \\
\hline \multicolumn{6}{|c|}{ förrsdorf et al. 1998a:74-5. } \\
\hline \multicolumn{6}{|c|}{ gGörsdorf 2002:558. } \\
\hline be & 04 . & & & & \\
\hline
\end{tabular}


Appendix $2{ }^{14} \mathrm{C}$ dates of the Okunevo culture: previous research $(n=14)$.

\begin{tabular}{|c|c|c|c|c|c|}
\hline Lab ID & Material & $\begin{array}{l}\delta^{13} \mathrm{C} \\
(\% o)\end{array}$ & Provenance & ${ }^{14} \mathrm{C} \mathrm{BP}$ & $\begin{array}{l}\text { Age, cal BC } \\
(2 \sigma)\end{array}$ \\
\hline $\mathrm{B} \ln -4948^{\mathrm{a}}$ & charcoal & -24.30 & Chebaki, C-6 & $3664 \pm 37$ & 2190-1938 \\
\hline $\mathrm{B} \ln -4947^{\mathrm{a}}$ & charcoal & -24.14 & Chebaki, C-13 & $3488 \pm 40$ & $1916-1693$ \\
\hline $\mathrm{B} \ln -5279^{\mathrm{b}, \mathrm{c}}$ & human bone & -19.2 & Chernovaya, kurgan 1 , grave 1 & $3487 \pm 25$ & $1885-1745$ \\
\hline Le-519d & wood & - & Karasuk III, enclosure $7^{\mathrm{e}}$ & $3470 \pm 200$ & $2432-1316$ \\
\hline Le- $1315^{f}$ & charcoal & - & Lebyazhye, grave 10 & $4370 \pm 100$ & $3358-2708$ \\
\hline Le- $602^{d}$ & wood & - & Pristan I, enclosure 6 , grave 2 & $3750 \pm 60$ & 2399-1974 \\
\hline $\mathrm{B} \ln -5195^{\mathrm{g}}$ & human bone & -19.5 & Uibat $\mathrm{V}$, kurgan 1 , grave 1 & $3734 \pm 29$ & 2266-2034 \\
\hline ID $n / a^{h, i, j}$ & human bone & - & Uibat $\mathrm{V}$, kurgan 1 , grave 3 & $3830 \pm 25$ & $2456-2153$ \\
\hline $\mathrm{B} \ln -5196^{\mathrm{g}}$ & human bone & -19.5 & Uibat $\mathrm{V}$, kurgan 1 , grave 4 & $4016 \pm 30$ & $2618-2470$ \\
\hline $\mathrm{B} \ln -4951^{\mathrm{a}}$ & bone & -19.79 & Uibat $\mathrm{V}$, kurgan 4 , grave 4 & $3631 \pm 41$ & 2134-1891 \\
\hline $\mathrm{B} \ln -4762^{\mathrm{a}}$ & wood & - & Uibat $\mathrm{V}$, kurgan 4 , grave 5 & $3782 \pm 62$ & 2457-2033 \\
\hline $\mathrm{B} \ln -4950^{\mathrm{a}}$ & bone & -19.51 & Uibat $\mathrm{V}$, kurgan 4 , grave 15 & $3620 \pm 35$ & 2125-1890 \\
\hline $\mathrm{B} \ln -4949^{\mathrm{a}}$ & bone & -20.55 & Uibat $\mathrm{V}$, kurgan 4 , grave 20 & $3657 \pm 43$ & 2192-1916 \\
\hline Le-1178 h,k & - & - & Ust-Kindirla-1, settlement, dwelling 1 & $3410 \pm 50$ & $1881-1541$ \\
\hline
\end{tabular}

aGörsdorf et al. 1998a:74-5.

${ }^{\mathrm{b}}$ Görsdorf 2002:557.

${ }^{\mathrm{c}}$ Görsdorf et al. 2004:86.

${ }^{\mathrm{d}}$ Sementsov et al. 1969:258.

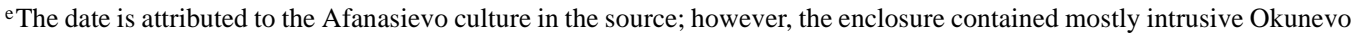
burials (Gryaznov 1999:36-7). Apparently, the date belongs to the Okunevo culture.

fZaitseva and van Geel 2004.

gGörsdorf et al. 2001:1116.

hLazaretov 1995:16.

${ }^{i}$ Lazaretov 2007:40

jLazaretov (1995) specifies that the date was obtained in the Heidelberg Radiocarbon Laboratory.

${ }^{\mathrm{k}}$ The site was originally attributed to the Neolithic period (Vadetskaya 1986:14); however, artifacts recovered from the settlement are very similar to those of the Okunevo culture. We propose that the site might belong to the Okunevo culture; therefore, the date is presented together with dates of the Okunevo culture.

Appendix $3{ }^{14} \mathrm{C}$ dates of the Andronovo culture: previous research $(n=20)$.

\begin{tabular}{|c|c|c|c|c|c|}
\hline Lab ID & Material & $\begin{array}{l}\delta^{13} \mathrm{C} \\
(\% o)\end{array}$ & Provenance & ${ }^{14} \mathrm{C} \mathrm{BP}$ & $\begin{array}{l}\text { Age, cal BC } \\
(2 \sigma)\end{array}$ \\
\hline Le-1867a & wood/charcoal & - & Ashpyl, kurgan 5 , grave 45 & $3490 \pm 40$ & $1918-1694$ \\
\hline Le-1866a & wood/charcoal & - & Ashpyl, kurgan 30 , grave 3 & $3580 \pm 40$ & 2034-1775 \\
\hline Le-3040 & - & - & Ashpyl, dwelling & $3360 \pm 40$ & $1742-1531$ \\
\hline Le- $2562^{b}$ & charcoal & - & Ashpyl, square E 4, 2nd spit & $4200 \pm 50$ & $2903-2630$ \\
\hline Le-3044 ${ }^{b}$ & - & - & Birya (Lebyazhye I) & $3340 \pm 60$ & $1769-1462$ \\
\hline Le-3045 & - & - & Birya (Lebyazhye I), grave 15 & $3060 \pm 200$ & 1744-819 \\
\hline Le-3046 ${ }^{\mathrm{b}}$ & - & - & Birya (Lebyazhye I), grave 16 & $3780 \pm 40$ & 2342-2041 \\
\hline Le- $604^{c}$ & wood & - & Kamenka II, enclosure 24 , grave 1 & $3910 \pm 75$ & $2579-2145$ \\
\hline Le-595c & wood & - & Kamenka II, enclosure 24 , grave 2 & $2540 \pm 65$ & $809-416$ \\
\hline Le- $630^{c}$ & wood & - & Lanin Log, enclosure 1, grave 1 & $3390 \pm 70$ & $1880-1523$ \\
\hline Le- $617^{c}$ & wood & - & Lanin Log, enclosure 1, grave 3 & $3660 \pm 65$ & 2274-1835 \\
\hline Le-619c & wood & - & Lanin Log, kurgan 2, grave 1 & $3970 \pm 70$ & $2838-2210$ \\
\hline $\mathrm{B} \ln -5163^{\mathrm{d}}$ & human bone & -19.3 & Potroshilovo II, enclosure 5, grave 1 & $3397 \pm 30$ & 1766-1617 \\
\hline $\mathrm{B} \ln -5194^{\mathrm{d}}$ & human bone & -20.4 & Potroshilovo II, enclosure 7 & $3295 \pm 32$ & 1664-1498 \\
\hline $\mathrm{B} \ln -5198^{\mathrm{d}}$ & human bone & -20.1 & Potroshilovo II, enclosure 5 , grave 2 & $3269 \pm 28$ & 1619-1460 \\
\hline $\mathrm{B} \ln -5197^{\mathrm{d}}$ & human bone & -19.7 & Potroshilovo II, enclosure 11 & $3189 \pm 28$ & 1507-1414 \\
\hline $\mathrm{B} \ln -5193^{\mathrm{d}}$ & human bone & -19.7 & Potroshilovo II, enclosure 20 & $3164 \pm 28$ & $1497-1400$ \\
\hline $\mathrm{Le}-587^{\mathrm{c}}$ & wood & - & Uzhur, kurgan 14 , grave covering & $4600 \pm 250$ & 3943-2637 \\
\hline Le- $518^{c}$ & wood & - & Yarki II, grave 1 & $2370 \pm 95$ & $771-208$ \\
\hline Le-529c & wood & - & Yarki II, grave 2 & $2970 \pm 70$ & $1396-1005$ \\
\hline
\end{tabular}

${ }^{\mathrm{a} E r m o l o v a}$ and Markov 1983.

bZaitseva and van Geel 2004.

cSementsov et al. 1969:258-9.

${ }^{\mathrm{d}}$ Görsdorf et al. 2001:1116. 
Appendix $4{ }^{14} \mathrm{C}$ dates of the Karasuk culture: previous research $(n=63)$.

\begin{tabular}{|c|c|c|c|c|c|}
\hline Lab ID & Material & $\begin{array}{l}\delta^{13} \mathrm{C} \\
(\% o)\end{array}$ & Provenance & ${ }^{14} \mathrm{C} \mathrm{BP}$ & $\begin{array}{l}\text { Age, cal BC } \\
(2 \sigma)\end{array}$ \\
\hline \multicolumn{6}{|c|}{ Karasuk phase $(n=26)$} \\
\hline Le-5283a & animal bone & - & Anchil-Chon, kurgan 1, grave 1 & $2660 \pm 100$ & $1054-418$ \\
\hline Le-5284, c & bone & - & Anchil-Chon, kurgan 1, grave 1 & $2880 \pm 70$ & $1294-896$ \\
\hline Le-5285 ${ }^{\mathrm{a}}$ & bone & - & Anchil-Chon, kurgan 1, grave 3 & $3470 \pm 100$ & $2033-1526$ \\
\hline Le-5293a & bone & - & Anchil-Chon, kurgan 1, grave 4 & $2960 \pm 45$ & $1368-1022$ \\
\hline Le-5287a & bone & - & Anchil-Chon, kurgan 1, grave 4 & $2950 \pm 25$ & $1262-1056$ \\
\hline Le-5289a & animal bone & - & Anchil-Chon, kurgan 1, grave 7 & $2970 \pm 25$ & $1300-1118$ \\
\hline Le-5290a & bone & - & Anchil-Chon, kurgan 1 , grave 8 & $2920 \pm 50$ & $1292-946$ \\
\hline Le-5286 ${ }^{\mathrm{a}}$ & animal bone & - & Anchil-Chon, kurgan 1, grave 9 & $2890 \pm 50$ & $1257-928$ \\
\hline Le-6299a & bone & - & Anchil-Chon, kurgan 2, grave 1 & $2880 \pm 90$ & $1367-838$ \\
\hline Le-4141 b,c & charcoal & - & $\begin{array}{l}\text { Georgievskiy Necropolis (Tes), } \\
\text { kurgan 1213, grave } 1\end{array}$ & $2880 \pm 40$ & $1208-930$ \\
\hline Le- $8193^{d}$ & animal bone & - & Itkol I, kurgan 40 & $2870 \pm 100$ & $1369-827$ \\
\hline $\mathrm{B} \ln -5165^{\mathrm{e}}$ & human bone & -15.4 & Potroshilovo, grave 1 & $2905 \pm 26$ & $1208-1009$ \\
\hline $\mathrm{B} \ln -5164^{\mathrm{e}}$ & human bone & -17.7 & Potroshilovo, grave7 & $2994 \pm 26$ & $1370-1128$ \\
\hline $\mathrm{B} \ln -5311^{\mathrm{f}, \mathrm{g}}$ & human bone & -16.3 & Sukhanikha I, grave 1 , object I & $3134 \pm 27$ & $1493-1318$ \\
\hline $\mathrm{B} \ln -5318^{\mathrm{f}, \mathrm{g}}$ & human bone & -15.2 & Sukhanikha I, grave 1 , object VI/3 & $3101 \pm 26$ & $1431-1311$ \\
\hline$B \ln -5312^{\mathrm{f}, \mathrm{g}}$ & human bone & -18.0 & Sukhanikha I, grave 1 , object VIII & $3006 \pm 30$ & $1379-1130$ \\
\hline $\mathrm{B} \ln -5314^{\mathrm{f}, \mathrm{g}}$ & human bone & -17.1 & Sukhanikha I, grave 1 , object 8 & $2987 \pm 27$ & $1368-1125$ \\
\hline$B \ln -5319^{\mathrm{f}, \mathrm{g}}$ & human bone & -17.1 & Sukhanikha I, grave 3 , object VIII & $2985 \pm 26$ & $1366-1125$ \\
\hline $\mathrm{B} \ln -5592^{\mathrm{h}}$ & animal bone & -19.7 & Sukhanikha & $2876 \pm 29$ & $1190-937$ \\
\hline $\mathrm{B} \ln -5593^{\mathrm{h}}$ & animal bone & -19.8 & Sukhanikha & $2871 \pm 28$ & $1187-933$ \\
\hline Bln-5594h & human bone & -18.1 & Sukhanikha & $812 \pm 36$ & AD $1165-1273$ \\
\hline Le-5396c & bone & - & Tert-Aba, enclosure $21 \mathrm{~b}$ & $2890 \pm 100$ & $1374-841$ \\
\hline Le- $4704^{\mathrm{b}, \mathrm{c}}$ & wood & - & Torgajak, dwelling 1 , western part & $2600 \pm 40$ & $837-559$ \\
\hline Le- $4706^{\text {b,c }}$ & wood & - & Torgajak, dwelling 1 , western part & $2580 \pm 80$ & $897-417$ \\
\hline Le-4707b,c & wood & - & Torgajak, dwelling 1 , western part & $2900 \pm 60$ & $1288-919$ \\
\hline Le-4708, c & wood & - & Torgajak, dwelling 5, depth $1 \mathrm{~m}$ & $2870 \pm 50$ & $1212-911$ \\
\hline \multicolumn{6}{|c|}{ Kamenniy Log phase $(n=37)$} \\
\hline Le- $6300^{c}$ & bone & - & Anchil-Chon, kurgan 3b, grave 1 & $2760 \pm 30$ & $994-830$ \\
\hline Le- $5707^{c}$ & coal & - & Anchil-Chon, kurgan 3v & $3070 \pm 100$ & $1525-1020$ \\
\hline Le- $5545^{c}$ & bone & - & Anchil-Chon, kurgan 3v & $2720 \pm 50$ & $976-800$ \\
\hline Le-5507c & bone & - & Anchil-Chon, kurgan 3g & $3280 \pm 100$ & $1874-1319$ \\
\hline Le- $5705^{c}$ & bone & - & Anchil-Chon, kurgan $3 \mathrm{~g}$ & $2800 \pm 35$ & $1044-845$ \\
\hline Le-6297c & bone & - & Anchil-Chon, kurgan 6 , grave 1 & $2940 \pm 55$ & 1371-997 \\
\hline Le-6298c & bone & - & Anchil-Chon, kurgan $7 \mathrm{a}$, grave 1 & $2740 \pm 40$ & $976-810$ \\
\hline Le-5704c & bone & - & Anchil-Chon, kurgan 7b & $2710 \pm 50$ & $975-797$ \\
\hline Le- $5706^{c}$ & bone & - & Anchil-Chon, kurgan $7 \mathrm{v}$ & $3000 \pm 60$ & $1401-1055$ \\
\hline Ua-24153i & bone & - & Kamenniy Ostrov & $2780 \pm 40$ & $1017-829$ \\
\hline Le-2046 ${ }^{\text {b,c }}$ & wood & - & Dolgiy Kurgan, kurgan 3 & $2850 \pm 40$ & $1187-905$ \\
\hline Le- $577^{j}$ & wood & - & Karasuk IV, kurgan 19 , grave 2 & $2710 \pm 75$ & $1053-675$ \\
\hline Le- $695^{j}$ & charcoal & - & Karasuk IV, kurgan 10 , grave 2 & $2930 \pm 60$ & 1369-939 \\
\hline Le- $1862^{\mathrm{b}, \mathrm{c}}$ & wood & - & Kolok, kurgan 10, grave 1 & $2830 \pm 50$ & $1129-843$ \\
\hline Le- $4327^{\mathrm{k}}$ & wood & - & Kuten-Buluk, kurgan 2, grave 1 & $2860 \pm 100$ & $1311-818$ \\
\hline Le- $4329^{k}$ & wood & - & Kuten-Buluk, kurgan 9, grave 1 & $2910 \pm 40$ & $1260-997$ \\
\hline Le- $4330^{\mathrm{k}}$ & wood & - & Kuten-Buluk, kurgan 11, grave 1 & $2890 \pm 50$ & $1257-928$ \\
\hline Le- $4326^{\mathrm{k}}$ & wood & - & Kuten-Buluk, kurgan 2, grave 2 & $2790 \pm 40$ & $1039-835$ \\
\hline Le- $4323^{\mathrm{k}}$ & wood & - & Kuten-Buluk, kurgan 6 , grave 2 & $2750 \pm 40$ & $996-816$ \\
\hline Le- $4328^{\mathrm{k}}$ & wood & - & Kuten-Buluk, kurgan 8 , grave 2 & $2750 \pm 40$ & $996-816$ \\
\hline Le-4324k & wood & - & Kuten-Buluk, kurgan 10 , grave 1 & $2790 \pm 40$ & $1039-835$ \\
\hline Le-4331k & wood & - & Kuten-Buluk, kurgan 12, grave 1 & $2770 \pm 40$ & $1008-828$ \\
\hline Le- $4325^{\mathrm{k}}$ & wood & - & Kuten-Buluk, kurgan 14, grave 1 & $2700 \pm 50$ & $972-794$ \\
\hline Le- $4322^{b, c}$ & wood & - & Kyzlas, kurgan 2, grave 1 & $2990 \pm 190$ & $1662-800$ \\
\hline
\end{tabular}


Appendix $4{ }^{14} \mathrm{C}$ dates of the Karasuk culture: previous research $(n=63)$. (Continued)

\begin{tabular}{|c|c|c|c|c|c|}
\hline Lab ID & Material & $\begin{array}{l}\delta^{13} \mathrm{C} \\
(\% o)\end{array}$ & Provenance & ${ }^{14} \mathrm{C} \mathrm{BP}$ & $\begin{array}{l}\text { Age, cal BC } \\
(2 \sigma)\end{array}$ \\
\hline Bln- $4768^{1}$ & wood & -25.71 & Sukhanikha, grave 15 , object 4 & $3031 \pm 38$ & $1407-1132$ \\
\hline Bln-4962 1 & wood & -26.54 & Sukhanikha, grave 20 , object 4 & $2962 \pm 36$ & $1306-1052$ \\
\hline Bln-4921 $1^{1}$ & wood & -26.77 & Sukhanikha, grave 20 , object 4 & $2943 \pm 29$ & $1262-1050$ \\
\hline Bln- $4836^{1}$ & birch bark & -26.33 & Sukhanikha, grave 15 , object 4 & $2923 \pm 37$ & $1260-1010$ \\
\hline $\mathrm{B} \ln -4835^{1}$ & wood & -26.23 & Sukhanikha, grave 15 , object 4 & $2906 \pm 38$ & $1258-980$ \\
\hline $\mathrm{B} \ln -4763^{1}$ & charcoal & -24.09 & Sukhanikha, stone line, object 6 & $2762 \pm 49$ & $1014-812$ \\
\hline $\mathrm{B} \ln -5281^{\mathrm{g}, \mathrm{i}}$ & wood & -25.9 & $\begin{array}{l}\text { Sukhanikha (Podsukhanikha) II, } \\
\text { kurgan 11, grave } 1\end{array}$ & $3044 \pm 29$ & $1405-1216$ \\
\hline $\mathrm{B} \ln -5316^{\mathrm{g}, \mathrm{i}}$ & human bone & -15.8 & $\begin{array}{l}\text { Sukhanikha (Podsukhanikha) II, } \\
\text { kurgan 11 A, grave } 1\end{array}$ & $2833 \pm 27$ & 1108-909 \\
\hline $\mathrm{B} \ln -5317^{\mathrm{g}, \mathrm{i}}$ & human bone & -16.5 & $\begin{array}{l}\text { Sukhanikha (Podsukhanikha) II, } \\
\text { kurgan } 11 \text {, grave } 1\end{array}$ & $2810 \pm 25$ & $1026-900$ \\
\hline $\mathrm{B} \ln -5315^{\mathrm{g}, \mathrm{i}}$ & human bone & -17.7 & $\begin{array}{l}\text { Sukhanikha (Podsukhanikha) II, } \\
\text { kurgan } 10 \text {, grave } 1\end{array}$ & $2667 \pm 24$ & $895-797$ \\
\hline Le-2001 & wood & - & Uij, kurgan 1 , grave 1 & $2690 \pm 40$ & $912-798$ \\
\hline Le-2002 $2^{\mathrm{b}, \mathrm{c}}$ & wood & - & Uij, kurgan 1 , grave 1 & $2630 \pm 40$ & $895-675$ \\
\hline Le- $2003^{\text {b,c }}$ & wood & - & Uij, kurgan 1 , grave 1 & $2610 \pm 40$ & $893-593$ \\
\hline
\end{tabular}

${ }^{\mathrm{a} B}$ Bokovenko and Legrand 2000.

${ }^{b}$ Alekseev et al. 2001.

cAlekseev et al. 2005.

${ }^{\mathrm{d}} \mathrm{A}$ Polyakov and S Morozov, unpublished data.

${ }^{\mathrm{e}}$ Görsdorf et al. 2001.

${ }^{\mathrm{f}}$ Görsdorf 2002:558.

gGörsdorf et al. 2004.

hGörsdorf 2004:407.

${ }^{\mathrm{i}}$ Grachev 2006.

${ }^{\mathrm{j} S e m e n t s o v}$ et al. 1969:259.

kLazaretov 2006.

${ }^{\mathrm{I} G o ̈ r s d o r f ~ e t ~ a l . ~ 1998 a . ~}$

Appendix $5{ }^{14} \mathrm{C}$ dates of the Tagar culture: previous research $(n=158)$.

\begin{tabular}{|c|c|c|c|c|c|}
\hline Lab ID & Material & $\begin{array}{l}\delta^{13} \mathrm{C} \\
(\% o)\end{array}$ & Provenance & ${ }^{14} \mathrm{C} \mathrm{BP}$ & $\begin{array}{l}\text { Age, cal BC } \\
(2 \sigma)\end{array}$ \\
\hline \multicolumn{6}{|c|}{ Bainovo phase $(n=7)$} \\
\hline Le- $5255^{a, b}$ & wood (charcoal) & - & Khystaglar, barrow 1 , fence A & $2710 \pm 70$ & 1024-774 BC \\
\hline Le- $5256^{a, b}$ & wood & - & $\begin{array}{l}\text { Khystaglar, barrow } 1 \text {, fence A, } \\
\text { grave } 1\end{array}$ & $2950 \pm 70$ & 1386-977 BC \\
\hline Le-c,d & wood & - & $\begin{array}{l}\text { Khystaglar, barrow } 1 \text {, fence A, } \\
\text { grave } 1\end{array}$ & $2620 \pm 40$ & $895-669 \mathrm{BC}$ \\
\hline Le-5254 a,b & wood & - & $\begin{array}{l}\text { Khystaglar, barrow } 1 \text {, fence } B \text {, } \\
\text { grave } 1\end{array}$ & $2950 \pm 30$ & $1268-1050 \mathrm{BC}$ \\
\hline Le-5257a,b & wood & - & $\begin{array}{l}\text { Khystaglar, barrow } 1 \text {, fence B, } \\
\text { grave } 1\end{array}$ & $2840 \pm 30$ & 1113-916 BC \\
\hline $\mathrm{B} \ln -5166^{\mathrm{e}}$ & human bone & -15.6 & Krivaya, grave 1 & $2552 \pm 32$ & $802-548 \mathrm{BC}$ \\
\hline Le-2096 ${ }^{a, b}$ & wood & - & Letnik-6, kurgan 10 & $2430 \pm 40$ & $753-402 \mathrm{BC}$ \\
\hline \multicolumn{6}{|c|}{ Podgornovo phase $(n=32)$} \\
\hline Le- $1896^{\mathrm{f}}$ & wood/charcoal & - & Ashpyl, kurgan 5 , grave 3 & $2360 \pm 40$ & $730-373 \mathrm{BC}$ \\
\hline Le- $2128^{f}$ & wood/charcoal & - & Ashpyl, kurgan 16 , grave 2 & $2390 \pm 40$ & $747-389 \mathrm{BC}$ \\
\hline Le- $2126^{f}$ & wood/charcoal & - & Ashpyl, kurgan 22 & $2360 \pm 40$ & $730-373 \mathrm{BC}$ \\
\hline Le- $2127^{f}$ & wood/charcoal & - & Ashpyl, kurgan 23 , grave 2 & $2330 \pm 40$ & $521-231 \mathrm{BC}$ \\
\hline Le-2124f & wood/charcoal & - & Ashpyl, kurgan 24 , grave 1 & $2380 \pm 40$ & $741-386 \mathrm{BC}$ \\
\hline Le- $1613^{f}$ & wood/charcoal & - & Ashpyl, kurgan 26 , grave 1 & $2660 \pm 40$ & $900-790 \mathrm{BC}$ \\
\hline
\end{tabular}


Appendix $5{ }^{14} \mathrm{C}$ dates of the Tagar culture: previous research $(n=158)$. (Continued)

\begin{tabular}{|c|c|c|c|c|c|}
\hline Lab ID & Material & $\begin{array}{l}\delta^{13} \mathrm{C} \\
(\% o) \\
\end{array}$ & Provenance & ${ }^{14} \mathrm{C} \mathrm{BP}$ & $\begin{array}{l}\text { Age, cal BC } \\
(2 \sigma)\end{array}$ \\
\hline Le-2099f & wood/charcoal & - & Ashpyl, kurgan 26 , grave 1 & $2630 \pm 40$ & $895-675 \mathrm{BC}$ \\
\hline Le-1614 ${ }^{\mathrm{f}}$ & wood/charcoal & - & Ashpyl, kurgan 26, grave 2 & $2300 \pm 40$ & 412-207 BC \\
\hline Le-2100 f & wood/charcoal & - & Ashpyl, kurgan 26 , grave 2 & $2310 \pm 40$ & $503-208 \mathrm{BC}$ \\
\hline Le- $5133^{b, g}$ & wood & - & Bolshaya Erba I, barrow 4, grave 2 & $2840 \pm 35$ & 1115-914 BC \\
\hline Le-5135a $\mathrm{a}^{\mathrm{b}, \mathrm{g}}$ & wood & - & $\begin{array}{l}\text { Bolshaya Erba I, barrow 4, grave } 2 \text {, } \\
20 \text { outer rings }\end{array}$ & $2780 \pm 40$ & $1017-829 \mathrm{BC}$ \\
\hline Le-5135b b,g & wood & - & $\begin{array}{l}\text { Bolshaya Erba I, barrow 4, grave } 2 \text {, } \\
30 \text { inner rings }\end{array}$ & $2730 \pm 25$ & $920-819 \mathrm{BC}$ \\
\hline Le-5398a & bone & - & Iyusskiy Mogilnik, kurgan slope & $2510 \pm 50$ & 795-417 BC \\
\hline Le-5190 b,g & bone & - & Kazanovka-2, kurgan 1 , grave 1 & $2720 \pm 80$ & $1112-769 \mathrm{BC}$ \\
\hline Le-5388a,b & bone & - & Kazanovka-2, kurgan 1 , fence D & $2670 \pm 80$ & $1018-546 \mathrm{BC}$ \\
\hline Le- $5137^{b, g}$ & wood & - & Kazanovka-2, kurgan 3 , grave A & $2665 \pm 30$ & $895-795 \mathrm{BC}$ \\
\hline Le-5391 b,g & bone & - & $\begin{array}{l}\text { Kazanovka-3, kurgan 2, fence A, } \\
\text { sk. B }\end{array}$ & $2620 \pm 40$ & $895-669$ BC \\
\hline Le-5393a,b & bone & - & $\begin{array}{l}\text { Kazanovka-3, kurgan 2, fence G, } \\
\text { grave } 2\end{array}$ & $2820 \pm 100$ & $1264-803 \mathrm{BC}$ \\
\hline Le- $5646^{\mathrm{h}}$ & bone & - & Kazanovka-3, kurgan 2a, grave 2 & $2640 \pm 120$ & $1048-410 \mathrm{BC}$ \\
\hline Le-720i & & - & Kickik-Kyuzyur-1, kurgan 1 & $2410 \pm 50$ & 753-395 BC \\
\hline Le-2114 & wood & - & Letnik- 6 , kurgan 12 & $2610 \pm 40$ & $893-593 \mathrm{BC}$ \\
\hline Le- $2113^{b, f}$ & wood & - & Letnik-6, kurgan 12 & $2630 \pm 40$ & $895-675$ BC \\
\hline Le- $2118^{b, f}$ & wood & - & Letnik-6, kurgan 38 & $2580 \pm 40$ & $820-549$ BC \\
\hline Le-2119 & wood & - & Letnik-6, kurgan 38 & $2590 \pm 40$ & $829-554 \mathrm{BC}$ \\
\hline Le- $5651^{\mathrm{h}}$ & bone & - & Pechische, barrow 3 , grave 3 & $2480 \pm 50$ & $772-414 \mathrm{BC}$ \\
\hline Le-5296 ${ }^{\mathrm{a}, \mathrm{b}}$ & bone & - & Prigorsk-1, kurgan 1, grave1 & $2365 \pm 45$ & $746-365 \mathrm{BC}$ \\
\hline Le-5295a,b & wood & - & Prigorsk-1, kurgan 1 , grave2 & $2500 \pm 30$ & $781-519 \mathrm{BC}$ \\
\hline Bln-5313 & human bone & -18.5 & Sukhanikha II, kurgan 14, grave 1 & $2651 \pm 26$ & $891-791 \mathrm{BC}$ \\
\hline Le-5192 b,g & wood & - & $\begin{array}{l}\text { Shaman Gora, kurgan 1, grave } 2 \text {, } \\
\text { bottom }\end{array}$ & $2700 \pm 30$ & 904-806 BC \\
\hline Le- $1880^{f}$ & wood/charcoal & - & Tigey, 1 grave & $2330 \pm 40$ & $521-231 \mathrm{BC}$ \\
\hline Le-5786 ${ }^{b}$ & & - & Tigir-Taidzhen-4, kurgan 1 & $2750 \pm 20$ & $968-833 \mathrm{BC}$ \\
\hline Le- $5838^{\mathrm{h}}$ & wood & - & Tigir-Taidzhen-4, kurgan 1 & $2780 \pm 30$ & $1003-843 \mathrm{BC}$ \\
\hline \multicolumn{6}{|c|}{ Saragash phase $(n=86)$} \\
\hline UB-4957k,1 & wood & - & Ai-Dai & $2440 \pm 16$ & $742-410 \mathrm{BC}$ \\
\hline Le-7511 & wood & & $\begin{array}{l}\text { Apchinaev, kurgan } 3 \text {, grave } 1 \text {, cov- } \\
\text { ering }\end{array}$ & $2560 \pm 25$ & $802-567 \mathrm{BC}$ \\
\hline Le- $2866^{\mathrm{m}}$ & & - & Balalyk-1, kurgan 6 , grave 2 & $2850 \pm 40$ & $1187-905$ BC \\
\hline Le-5679b,h & wood & - & $\begin{array}{l}\text { Cheremshino, barrow, grave } 1, \log \text {, } \\
4 \text { layer from center }\end{array}$ & $2370 \pm 20$ & 510-393 BC \\
\hline Le-5678 b,h & wood & - & $\begin{array}{l}\text { Cheremshino, barrow, grave } 1, \log \text {, } \\
3 \text { layer from center }\end{array}$ & $2400 \pm 20$ & $701-400 \mathrm{BC}$ \\
\hline Le-5677b,h & wood & - & $\begin{array}{l}\text { Cheremshino, barrow, grave } 1, \log \text {, } \\
2 \text { layer from center }\end{array}$ & $2540 \pm 40$ & $801-539$ BC \\
\hline Le- $5676^{\text {b,h }}$ & wood & - & $\begin{array}{l}\text { Cheremshino, barrow, grave } 1, \log \text {, } \\
1 \text { layer from center }\end{array}$ & $2710 \pm 60$ & $997-795$ BC \\
\hline Le- $5680^{\mathrm{b}, \mathrm{h}}$ & wood & - & $\begin{array}{l}\text { Cheremshino, barrow, grave } 1 \text {, } \\
\text { outer rings }\end{array}$ & $2435 \pm 25$ & $748-406$ BC \\
\hline Le-5670 b,h & wood & - & Cheremshino, barrow 1 , grave 3 & $2470 \pm 30$ & $762-416 \mathrm{BC}$ \\
\hline Le-5668 b,h & wood & - & Cheremshino, barrow 1, grave 2 & $2530 \pm 25$ & 793-547 BC \\
\hline Le-5671 b,h & wood & - & Cheremshino, barrow 1 , grave 3 & $2610 \pm 50$ & $896-553$ BC \\
\hline Le-5672b,h & wood & - & $\begin{array}{l}\text { Cheremshino, barrow } 1 \text {, grave } 1 \text {, } \\
\text { outer rings }\end{array}$ & $2660 \pm 60$ & 976-598 BC \\
\hline Le- $5675^{\text {b,h }}$ & wood & - & $\begin{array}{l}\text { Cheremshino, barrow } 1 \text {, grave } 1 \text {, } \\
\text { central rings }\end{array}$ & $2700 \pm 50$ & $972-794 \mathrm{BC}$ \\
\hline Le-720a & wood & - & Kichik-Kyuzyur-1, kurgan 1 & $2410 \pm 80$ & $780-379 \mathrm{BC}$ \\
\hline Le- $721^{\mathrm{i}}$ & & - & Kichik-Kyuzyur, kurgan 7, burial 5 & $2180 \pm 50$ & $383-103 \mathrm{BC}$ \\
\hline
\end{tabular}


Appendix $5{ }^{14} \mathrm{C}$ dates of the Tagar culture: previous research $(n=158)$. (Continued)

\begin{tabular}{|c|c|c|c|c|c|}
\hline Lab ID & Material & $\begin{array}{l}\delta^{13} \mathrm{C} \\
(\% o) \\
\end{array}$ & Provenance & ${ }^{14} \mathrm{C}$ BP & $\begin{array}{l}\text { Age, cal BC } \\
(2 \sigma)\end{array}$ \\
\hline Le-2203 ${ }^{a, b}$ & wood & - & Kirbinskiy Log, kurgan 1 , grave 2 & $2210 \pm 40$ & $385-185 \mathrm{BC}$ \\
\hline Le-2204 & wood & - & Kirbinskiy Log, kurgan 1, grave 2 & $2280 \pm 40$ & 403-208 BC \\
\hline Le-2205 ${ }^{a, b}$ & wood & - & Kirbinskiy Log, kurgan 2 & $2220 \pm 40$ & 387-197 BC \\
\hline Le-2208 ${ }^{a, b}$ & wood & - & Kirbinskiy Log, kurgan 4, grave 1 & $2340 \pm 40$ & 705-234 BC \\
\hline Le-2209m & & - & Kirbinskiy Log & $3840 \pm 40$ & 2462-2154 BC \\
\hline Le-2210 & wood & - & Kirbinskiy Log, kurgan 5, grave 1 & $2380 \pm 40$ & 741-386 BC \\
\hline Le-2211 a,b & wood & - & Kirbinskiy Log, kurgan 5, grave 2 & $2410 \pm 40$ & $750-396 \mathrm{BC}$ \\
\hline Le-2305 ${ }^{\mathrm{a}, \mathrm{b}}$ & wood & - & Kirbinskiy Log, kurgan 3, grave 4 & $2180 \pm 40$ & $378-114 \mathrm{BC}$ \\
\hline Le- $1864^{b, f}$ & wood & - & Kolok, kurgan 3 , grave 1 & $2690 \pm 50$ & 970-791 BC \\
\hline Le- $2097^{f}$ & wood/charcoal & - & Kolok, kurgan 3 , grave 1 & $2640 \pm 40$ & $895-773 \mathrm{BC}$ \\
\hline Le- $1865^{f}$ & wood/charcoal & - & Kolok, kurgan 3, grave 2 & $2110 \pm 40$ & $350-4 \mathrm{BC}$ \\
\hline Le-2098f & wood/charcoal & - & Kolok, kurgan 3, grave 1 & $2130 \pm 40$ & 354-46 BC \\
\hline Le- $1863^{b, f}$ & wood & - & Kolok, kurgan 9, grave 1 & $2400 \pm 50$ & $752-391 \mathrm{BC}$ \\
\hline Le-2095 f & wood/charcoal & - & Kolok, kurgan 9, grave 1 & $2380 \pm 40$ & $741-386$ BC \\
\hline Le-2096 ${ }^{f}$ & wood/charcoal & - & Kolok, kurgan 10 , grave 1 & $2430 \pm 20$ & $735-407 \mathrm{BC}$ \\
\hline Le- $5134 b^{b, g}$ & wood & - & $\begin{array}{l}\text { Kobyak, kurgan } 5 \text {, grave } 1,18 \text { cen- } \\
\text { tral rings }\end{array}$ & $2840 \pm 30$ & $1113-916$ BC \\
\hline Le-5134a $a^{b, g}$ & wood & - & $\begin{array}{l}\text { Kobyak, kurgan 5, grave 1, } 20 \text { mid- } \\
\text { dle rings }\end{array}$ & $2790 \pm 35$ & $1017-839 \mathrm{BC}$ \\
\hline Le-5191 b,g & wood & - & $\begin{array}{l}\text { Kobyak, kurgan } 5 \text {, grave } 1 \text {, outer } \\
\text { rings }\end{array}$ & $2640 \pm 25$ & $835-790 \mathrm{BC}$ \\
\hline Le-5190 b,g & wood & - & Kobyak, kurgan 5, grave 2 & $2470 \pm 30$ & $762-416 \mathrm{BC}$ \\
\hline Le-2095 ${ }^{a, b}$ & wood & - & Letnik-6, kurgan 9, grave 1 & $2380 \pm 40$ & $741-386$ BC \\
\hline Le-2036 & wood & - & Medvedka-1, kurgan 1 , grave 2 & $1980 \pm 40$ & $87 \mathrm{BC}-\mathrm{AD} 124$ \\
\hline Le-2040g & wood & - & Medvedka-1, kurgan 1 , grave 2 & $2060 \pm 40$ & $184 \mathrm{BC}-\mathrm{AD} 24$ \\
\hline Le-2045g & wood & - & Medvedka-1, kurgan 4 & $2030 \pm 40$ & $164 \mathrm{BC}-\mathrm{AD} 57$ \\
\hline Le-2044g & wood & - & Medvedka-1, kurgan 3 , grave 2 & $2010 \pm 40$ & $154 \mathrm{BC}-\mathrm{AD} 74$ \\
\hline Le-2007 b,g & wood & - & $\begin{array}{l}\text { Medvedka-2, kurgan } 1, \text { grave } 1,12 \\
\text { central rings }\end{array}$ & $2560 \pm 40$ & 809-543 BC \\
\hline Le-2007a $a^{b, g}$ & wood & - & $\begin{array}{l}\text { Medvedka-2, kurgan } 1 \text {, grave } 1 \text {, } \\
\text { rings } 12-24\end{array}$ & $2520 \pm 40$ & 796-517 BC \\
\hline Le-2008 & wood & - & $\begin{array}{l}\text { Medvedka-2, kurgan 1, grave } 1 \text {, } \\
\text { NW corner }\end{array}$ & $2090 \pm 40$ & $337 \mathrm{BC}-\mathrm{AD} 1$ \\
\hline Le- $2008 b^{b}$ & wood & - & $\begin{array}{l}\text { Medvedka-2, kurgan 1, grave } 1 \text {, } \\
\text { NW corner }\end{array}$ & $2080 \pm 40$ & $200 \mathrm{BC}-\mathrm{AD} 3$ \\
\hline Le-2008 $c^{b}$ & wood & - & $\begin{array}{l}\text { Medvedka- } 2 \text {, kurgan } 1 \text {, grave } 1 \text {, } \\
\text { NW corner }\end{array}$ & $2090 \pm 40$ & $337 \mathrm{BC}-\mathrm{AD} 1$ \\
\hline Le-2009 ${ }^{b}$ & wood & - & $\begin{array}{l}\text { Medvedka-2, kurgan 1, grave 1, } \\
\text { floor }\end{array}$ & $2720 \pm 40$ & 971-804 BC \\
\hline Le- $2010^{\mathrm{b}}$ & wood & - & Medvedka-2, kurgan 1 , grave 1 & $1980 \pm 40$ & $87 \mathrm{BC}-\mathrm{AD} 124$ \\
\hline Le-2010a ${ }^{b}$ & wood & - & $\begin{array}{l}\text { Medvedka-2, kurgan } 1 \text {, grave } 1 \text {, } \\
\text { top }\end{array}$ & $1930 \pm 40$ & 39 BC-AD 209 \\
\hline Le-2010b ${ }^{b}$ & charcoal & - & Medvedka-2, kurgan 1 , grave 1 & $1890 \pm 40$ & AD 28-230 \\
\hline Le-2189 & wood & - & Medvedka-2, kurgan 2 , grave 1 & $2690 \pm 40$ & $912-798 \mathrm{BC}$ \\
\hline Le-2190 b,g & wood & - & $\begin{array}{l}\text { Medvedka-2, kurgan 2, grave } 1 \text {, } \\
\text { top }\end{array}$ & $2490 \pm 40$ & 780-416 BC \\
\hline Le-2191 ${ }^{b, g}$ & charcoal & - & $\begin{array}{l}\text { Medvedka-2, kurgan 2, grave } 2 \text {, } \\
\text { NW corner }\end{array}$ & $2470 \pm 40$ & 764-414 BC \\
\hline Le- $2193^{b}$ & wood & - & Medvedka-2, kurgan 2 , grave 2 & $2470 \pm 40$ & $764-414 \mathrm{BC}$ \\
\hline Le-2194b & wood & - & Medvedka-2, kurgan 2, grave 2 & $2230 \pm 40$ & $387-203$ BC \\
\hline Le- $2195^{\mathrm{b}}$ & wood & - & Medvedka-2, kurgan 2, grave 2 & $2270 \pm 40$ & 400-207 BC \\
\hline Le-2196 ${ }^{b}$ & wood & - & Medvedka-2, kurgan 3, grave 1 & $2490 \pm 40$ & $780-416$ BC \\
\hline Le-5138 b,g & fur & - & Medvedka-2, kurgan 1 , grave 1 & $2650 \pm 90$ & 1019-514 BC \\
\hline Le-5139b,g & textile & - & Medvedka-2, kurgan 1 , grave 1 & $2580 \pm 50$ & 834-539 BC \\
\hline Le- $5140^{\text {b,g }}$ & charcoal & - & Medvedka-2, kurgan 1 , grave 1 & $2540 \pm 60$ & $809-417$ BC \\
\hline
\end{tabular}


Appendix $5{ }^{14} \mathrm{C}$ dates of the Tagar culture: previous research $(n=158)$. (Continued)

\begin{tabular}{|c|c|c|c|c|c|}
\hline Lab ID & Material & $\begin{array}{l}\delta^{13} \mathrm{C} \\
(\% o) \\
\end{array}$ & Provenance & ${ }^{14} \mathrm{C}$ BP & $\begin{array}{l}\text { Age, cal BC } \\
(2 \sigma)\end{array}$ \\
\hline Le-4321 a,b & wood & - & $\begin{array}{l}\text { Novaya Mikhailovka, kurgan 1, } \\
\text { grave } 3\end{array}$ & $2350 \pm 50$ & $746-231 \mathrm{BC}$ \\
\hline Le- $722^{n}$ & & - & Novoselovo, kurgan 1, grave 1 & $2160 \pm 50$ & $366-56 \mathrm{BC}$ \\
\hline Le-1192 b,f & wood & - & Salbyk, floor & $2410 \pm 60$ & 756-394 BC \\
\hline Le-4771 a,b & wood & - & Salbyk, floor & $2490 \pm 40$ & 780-416 BC \\
\hline Le-5145 a,b & wood & - & Salbyk, 30 outer rings & $2460 \pm 40$ & $758-412 \mathrm{BC}$ \\
\hline Le-5297a,b & bone & - & Sarala, kurgan 2, grave 2 & $2445 \pm 20$ & 749-410 BC \\
\hline Le-5298a,b & bone & - & Sarala, kurgan 2, grave 4 & $2430 \pm 30$ & 749-404 BC \\
\hline Le-5299a,b & bone & - & Sarala, kurgan 2 , grave 1 & $2420 \pm 25$ & $736-403 \mathrm{BC}$ \\
\hline Le- $5652^{\circ}$ & bone & - & Sarala, kurgan 2, grave 1 & $2490 \pm 80$ & 789-412 BC \\
\hline Le-5300a,b & bone & - & Sarala, kurgan 2 , grave 3 & $2305 \pm 30$ & 407-234 BC \\
\hline$B \ln -5340^{j}$ & human bone & -19.1 & Sukhanikha II, kurgan 82 , grave 3 & $2389 \pm 26$ & $706-395 \mathrm{BC}$ \\
\hline$B \ln -5341^{j}$ & charcoal & -26.2 & Sukhanikha II, kurgan 82, grave 3 & $2543 \pm 26$ & $797-550 \mathrm{BC}$ \\
\hline$B \ln -5342^{\mathrm{j}}$ & charcoal & -25.7 & Sukhanikha II, kurgan 88 , grave 4 & $2563 \pm 24$ & $803-593$ BC \\
\hline$B \ln -5343^{j}$ & charcoal & -24.8 & Sukhanikha II, kurgan 93, grave 3 & $2541 \pm 23$ & $795-554 \mathrm{BC}$ \\
\hline$B \ln -5276^{j}$ & human bone & -16.9 & Sukhanikha II, kurgan 88 , grave 3 & $2448 \pm 27$ & $752-409 \mathrm{BC}$ \\
\hline$B \ln -5277^{j}$ & human bone & -17.5 & Sukhanikha II, kurgan 88 , grave 4 & $2519 \pm 27$ & $791-541 \mathrm{BC}$ \\
\hline$B \ln -5278^{j}$ & human bone & -16.3 & Sukhanikha II, kurgan 93, grave 4 & $2425 \pm 30$ & $748-402 \mathrm{BC}$ \\
\hline Le-696p & wood & - & Ulug-Kyuzyur I, kurgan 3 , grave 1 & $2450 \pm 50$ & $759-407 \mathrm{BC}$ \\
\hline Le- $2103^{f}$ & wood/charcoal & - & Znamenka, kurgan 13 & $1980 \pm 40$ & $87 \mathrm{BC}-\mathrm{AD} 124$ \\
\hline Le-2104f,i & wood & - & Znamenka, kurgan 13 & $2220 \pm 40$ & $387-197 \mathrm{BC}$ \\
\hline Le-2105,i & wood & - & Znamenka, kurgan 13 & $2250 \pm 40$ & 395-204 BC \\
\hline Le-2106 f,i & wood & - & Znamenka, kurgan 17 , grave 1 & $2270 \pm 40$ & 400-207 BC \\
\hline Le-2107 f,i & wood & - & Znamenka, kurgan 17 , grave 2 & $2250 \pm 40$ & 395-204 BC \\
\hline Le-2108f & wood/charcoal & - & Znamenka, kurgan 16 , grave 1 & $2030 \pm 40$ & $164 \mathrm{BC}-\mathrm{AD} 57$ \\
\hline Le-2109f,i & wood & - & Znamenka, kurgan 16 , grave 1 & $2220 \pm 40$ & 387-197 BC \\
\hline Le- $2110^{\mathrm{h}, \mathrm{i}}$ & wood & - & Znamenka, kurgan 16 , grave 1 & $2250 \pm 40$ & $395-204$ BC \\
\hline Le-2111 ${ }^{\mathrm{f}}$ & wood/charcoal & - & Znamenka, kurgan 12 , grave 2 & $2280 \pm 40$ & 403-208 BC \\
\hline Le- $2112^{\mathrm{f}}$ & wood/charcoal & - & Znamenka, kurgan 12 , grave 2 & $2250 \pm 40$ & 395-204 BC \\
\hline \multicolumn{6}{|c|}{ Tes phase $(n=33)$} \\
\hline Le- $1825^{\mathrm{f}}$ & wood/charcoal & - & Kadat, kurgan 4, grave 2 & $2210 \pm 40$ & $385-185 \mathrm{BC}$ \\
\hline Le- $1820^{f}$ & wood/charcoal & - & Kadat, kurgan 3 , grave 1 & $1950 \pm 40$ & $40 \mathrm{BC}-\mathrm{AD} 128$ \\
\hline Le- $1819^{f}$ & wood/charcoal & - & Kadat, kurgan 3, grave 2 & $1720 \pm 40$ & AD 237-412 \\
\hline Le-724i,o & wood & - & Kamenka III, grave 64 & $1790 \pm 60$ & AD 85-387 \\
\hline $\mathrm{B} \ln -4920^{\mathrm{k}, \mathrm{q}}$ & wood & -26.8 & Sukhanikha, grave 18 , object 4 & $2008 \pm 35$ & $101 \mathrm{BC}-\mathrm{AD} 72$ \\
\hline $\mathrm{B} \ln -4961^{\mathrm{n}, \mathrm{q}}$ & wood & -26.9 & Sukhanikha, grave 18 , object 4 & $1984 \pm 35$ & $84 \mathrm{BC}-\mathrm{AD} 116$ \\
\hline $\mathrm{B} \ln -4922^{\mathrm{n}, \mathrm{q}}$ & wood & -26.9 & Sukhanikha, grave 22 , object 4 & $2026 \pm 33$ & $156 \mathrm{BC}-\mathrm{AD} 55$ \\
\hline Le-2072f,i & wood & - & Tepsey-VII, grave 1 & $1850 \pm 40$ & 71 BC-AD 249 \\
\hline Le-2071 f,i & wood & - & Tepsey-VII, grave 1 & $1920 \pm 40$ & $18 \mathrm{BC}-\mathrm{AD} 214$ \\
\hline Le-2073, & wood & - & Tepsey-VII, grave 1 & $1930 \pm 40$ & 39 BC-AD 209 \\
\hline Le-2074f,i & wood & - & Tepsey-VII, grave 2 & $1980 \pm 40$ & $87 \mathrm{BC}-\mathrm{AD} 124$ \\
\hline Le-2075,i & wood & - & Tepsey-VII, grave 2 & $2010 \pm 40$ & $154 \mathrm{BC}-\mathrm{AD} 74$ \\
\hline Le-2076 f,i & wood & - & Tepsey-VII, grave 2 & $2020 \pm 40$ & 159 BC-AD 67 \\
\hline Le-2081,i & wood & - & Tepsey-VII, grave 92 & $1790 \pm 20$ & AD $137-323$ \\
\hline Le-2082f,i & wood & - & Tepsey-VII, grave 92 & $1830 \pm 40$ & AD 79-319 \\
\hline Le-2077f,i & wood & - & Tepsey-VII, grave 94 & $1800 \pm 40$ & AD 92-339 \\
\hline Le-2078,i & wood & - & Tepsey-VII, grave 94 & $1820 \pm 40$ & AD 85-322 \\
\hline Le-2079f,i & wood & - & Tepsey-VII, grave 96 & $1780 \pm 40$ & AD 130-378 \\
\hline Le-2080,i & wood & - & Tepsey-VII, grave 96 & $1810 \pm 40$ & AD 87-332 \\
\hline Le-2086 ${ }^{\mathrm{f}}$ & wood/charcoal & - & Tepsey-VII, grave 100 & $1840 \pm 40$ & AD 75-312 \\
\hline Le-2087f,i & wood & - & Tepsey-VII, grave 100 & $1890 \pm 40$ & AD 28-230 \\
\hline Le-2088,i & wood & - & Tepsey-VII, grave 100 & $1910 \pm 40$ & AD 5-216 \\
\hline Le-2089f,i & wood & - & Tepsey-VII, grave 105 & $1910 \pm 40$ & AD 5-216 \\
\hline
\end{tabular}


Appendix $5{ }^{14} \mathrm{C}$ dates of the Tagar culture: previous research $(n=158)$. (Continued)

\begin{tabular}{llllll}
\hline Lab ID & Material & $\begin{array}{c}\delta^{13} \mathrm{C} \\
(\%)\end{array}$ & Provenance & ${ }^{14}$ C BP & $\begin{array}{l}\text { Age, cal BC } \\
(2 \sigma)\end{array}$ \\
\hline Le-2090 & wood & - & Tepsey-VII, grave 105 & $1920 \pm 40$ & 18 BC-AD 214 \\
Le-2083f & wood/charcoal & - & Tepsey-VII, grave 112 & $1780 \pm 40$ & AD 130-378 \\
Le-2084,i & wood & - & Tepsey-VII, grave 112 & $1880 \pm 40$ & AD 34-236 \\
Le-2085 & wood & - & Tepsey-VII, grave 112 & $1900 \pm 40$ & AD 23-223 \\
Le-2069 & wood/charcoal & - & Tepsey-VII, crypt & $1830 \pm 40$ & AD 79-319 \\
Le-2068f & wood/charcoal & - & Tepsey-VII, crypt & $1840 \pm 40$ & AD 75-312 \\
Le-2065 & wood/charcoal & - & Tepsey-VII, crypt & $1860 \pm 40$ & AD 67-242 \\
Le-2067f & wood/charcoal & - & Tepsey-VII, crypt & $1870 \pm 40$ & AD 60-238 \\
Le-2066 & wood/charcoal & - & Tepsey-VII, crypt & $1900 \pm 40$ & AD 23-223 \\
Le-2070f & wood/charcoal & - & Tepsey-VII, crypt & $1850 \pm 40$ & AD 71-249 \\
\hline
\end{tabular}

${ }^{a}$ Alekseev et al. 2001

${ }^{b}$ Alekseev et al. 2005.

cID is uncertain.

dBokovenko 2006.

${ }^{\mathrm{e}}$ Görsdorf et al. 2001:1116.

${ }^{\mathrm{f}}$ Ermolova and Markov 1983.

${ }^{g}$ Sementsov et al. 1998.

${ }^{\text {h}}$ Alekseev et al. 2002.

${ }^{i}$ Hall 1999.

jGörsdorf 2002:557-9.

${ }^{\mathrm{k} B e e r} 2004$.

${ }^{1}$ The site is assigned to the transition between the Podgornovo and Saragash phases of the Tagar culture.

mZaitseva and van Geel 2004.

${ }^{\mathrm{n}}$ Görsdorf et al. 1998a:74-5.

o Semyontsov et al. 1972.

PSementsov et al. 1969:260.

${ }^{\mathrm{q}}$ Görsdorf et al. 1998b. 